\title{
Correlation of core and downhole seismic velocities in high-pressure metamorphic rocks: a case study for the COSC-1 borehole, Sweden
}

\author{
Felix Kästner ${ }^{1,2}$, Simona Pierdominici ${ }^{1}$, Judith Elger ${ }^{2}$, Alba Zappone ${ }^{3}$, Jochem Kück ${ }^{1}$, and Christian Berndt ${ }^{2}$ \\ ${ }^{1}$ Helmholtz Centre Potsdam, GFZ German Research Centre for Geosciences, 14473 Potsdam, Germany \\ ${ }^{2}$ GEOMAR Helmholtz Centre for Ocean Research Kiel, 24148 Kiel, Germany \\ ${ }^{3}$ Department of Earth Sciences, ETH Zurich, 8092 Zurich, Switzerland
}

Correspondence: Felix Kästner (felix.kaestner@gfz-potsdam.de)

Received: 18 October 2019 - Discussion started: 5 November 2019

Revised: 3 March 2020 - Accepted: 11 March 2020 - Published: 23 April 2020

\begin{abstract}
Deeply rooted thrust zones are key features of tectonic processes and the evolution of mountain belts. Exhumed and deeply eroded orogens like the Scandinavian Caledonides allow us to study such systems from the surface. Previous seismic investigations of the Seve Nappe Complex have shown indications of a strong but discontinuous reflectivity of this thrust zone, which is only poorly understood. The correlation of seismic properties measured on borehole cores with surface seismic data can constrain the origin of this reflectivity. To this end, we compare seismic velocities measured on cores to in situ velocities measured in the borehole. For some intervals of the COSC-1 borehole, the core and downhole velocities deviate by up to $2 \mathrm{~km} \mathrm{~s}^{-1}$. These differences in the core and downhole velocities are most likely the result of microcracks mainly due to depressurization. However, the core and downhole velocities of the intervals with mafic rocks are generally in close agreement. Seismic anisotropy measured in laboratory samples increases from about $5 \%$ to $26 \%$ at depth, correlating with a transition from gneissic to schistose foliation. Thus, metamorphic foliation has a clear expression in seismic anisotropy. These results will aid in the evaluation of core-derived seismic properties of high-grade metamorphic rocks at the COSC-1 borehole and elsewhere.
\end{abstract}

\section{Introduction}

Thrust zones in high-pressure metamorphic rocks are important features in mountain belts. In active fault zones they are often accompanied by devastating earthquakes, such as those repeatedly occurring in the Himalayas (e.g., in 2015, $M=7.9$, and 2008, $M=7.9$ ), which are a potential threat to the local population. Their investigation, therefore, is important to improve our understanding of the deeper orogenic processes and tectonic evolution.

However, such structures are seldom directly accessible and difficult to image. An exception are exhumed systems where most parts of the orogen were deeply eroded and exposed to upper crustal levels. The Caledonides of western Scandinavia, a remnant of the mid-Paleozoic Caledonian orogeny (e.g., Gee and Sturt, 1985), represent such a system. Here, available geophysical investigations of an orogen root can be compared to geological and petrophysical observations from the surface (e.g., Ebbing et al., 2012). Reflection seismic data provide another possibility to investigate these thrust zones and revealed structures of a strong and highly diffuse reflectivity as, for example, observed at the highly metamorphic Seve Nappe Complex in the Jämtland region, in central Sweden (e.g., Hedin et al., 2012).

To better understand the origin of these reflections, one can compare them to the physical properties of the related rocks at depths to characterize the impact of structural and compositional variations on seismic properties. This involves comparison of seismic velocities from different measurements and scales with both lithological and structural characteristics of cored rocks.

In this study, we determine seismic properties on core scale (millimeter to centimeter) from the COSC-1 borehole in western Jämtland, central Sweden (Fig. 1) and evaluate their potential to explain the in situ seismic properties (millimeter to kilometer scale) by comparing core velocities with 
(a)

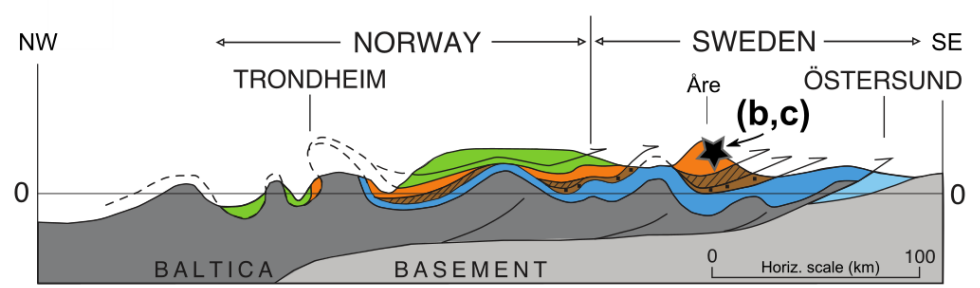

Upper and Middle Allochthons

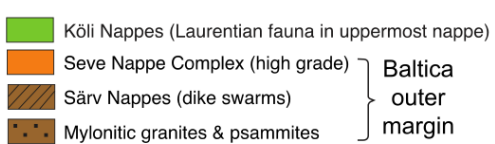

Lower Allochthon, Parautochthon, Autochthon

Baltoscandian foreland basin \& platform
Baltica basement (allochthonous \& autochthonous)

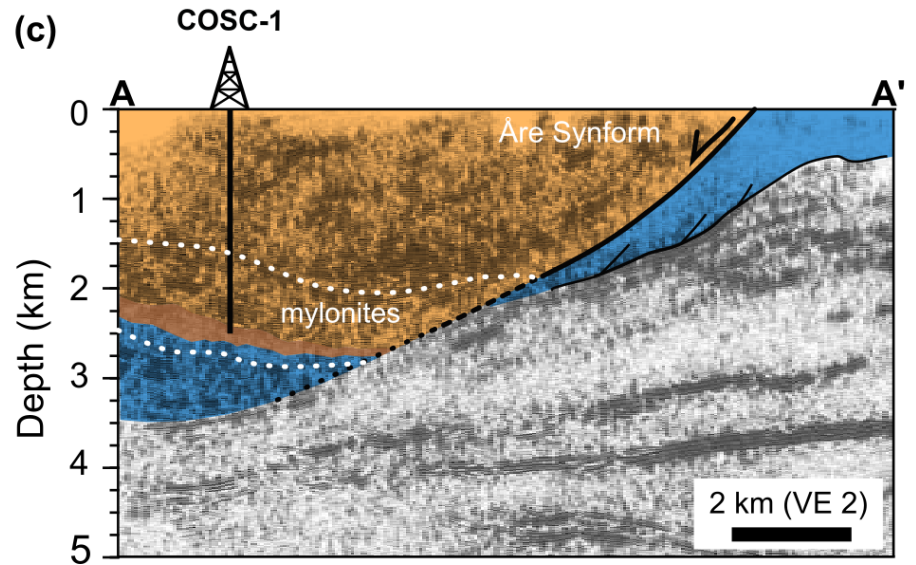

(b)

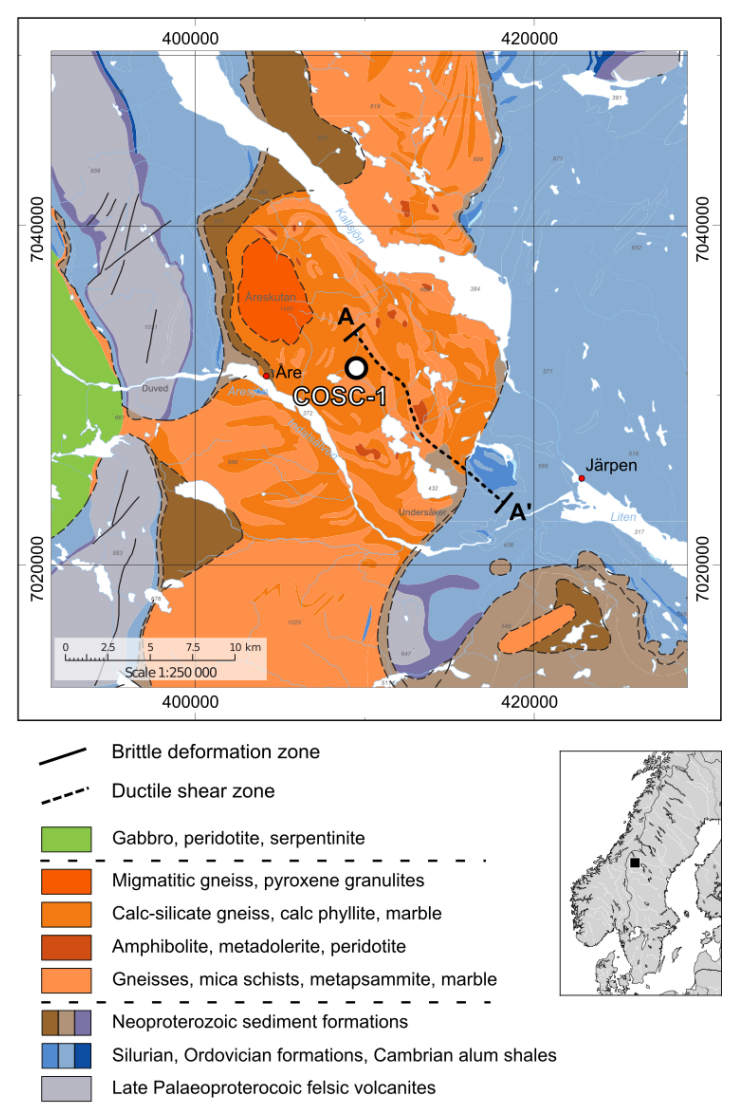

Figure 1. Overview of the regional setting and study area. (a) Tectonostratigraphic division of the central Scandinavian Caledonides (Gee et al., 2010; Lorenz et al., 2015a); (b) bedrock map with location of the COSC-1 borehole (colors modified; SGU Map Service; Strömberg et al., 1994); (c) seismic cross section indicated in (b) showing a part of the COSC seismic profile (Hedin et al., 2012) with the COSC-1 borehole penetrating the highly reflective Lower Seve Nappe (adapted from Juhlin et al., 2016).

downhole logging data (centimeter to meter scale) and core lithology. Moreover, we focus on the effects of different ambient pressure conditions on the velocities, the potential impact of microcracks and fracturing as well as scale differences inherent in the individual data sets and measurement procedures (Fig. 2).

As core velocities measured under atmospheric pressure conditions can exhibit strong deviations from in situ conditions (Elbra et al., 2011), we integrate and compare the core and downhole seismic velocities with laboratory velocity and anisotropy results from 16 core samples measured under different confining pressure to simulate in situ conditions. U1timately, this results in better constrained seismic properties in the vicinity of the COSC-1 borehole, which is a prerequisite for a successful core-log-seismic data integration (Worthington, 1994).

The concept of integration and cross-calibration of data sets across different scales is well established in sedimentary basins of marine and lake environments (e.g., Bloomer and Mayer, 1997; Miller et al., 2013; Riedel et al., 2013; Thu et al., 2002), where it was successfully used to better characterize the subsurface seismic stratigraphy using both core and downhole logging data. But to date, there are only few studies that have adapted this concept in hard-rock environments and similar metamorphic complexes. Some examples are the KTB borehole in Germany (Kern et al., 1991), the Kola super-deep borehole in Russia (Golovataya et al., 2006), the Chinese Continental Scientific Drilling borehole in China (Sun et al., 2012), and the Outokumpu deep drilling borehole in Finland (Kukkonen, 2011).

The project COSC (Collisional Orogeny in the Scandinavian Caledonides) is a scientific drilling project co-funded by the International Continental Scientific Drilling Program (ICDP), the Swedish Research Council, and the Geological Survey of Sweden. It generally aims to study the mountain building processes of the Scandinavian Caledonides in Sweden (Gee et al., 2010; Lorenz et al., 2015a). In 2014, the COSC-1 borehole was drilled in Åre, Jämtland (Fig. 1) to a total depth of $2495.8 \mathrm{~m}$. It was fully cored below $103 \mathrm{~m}$ with almost $100 \%$ core recovery. Drilling was accompanied by 


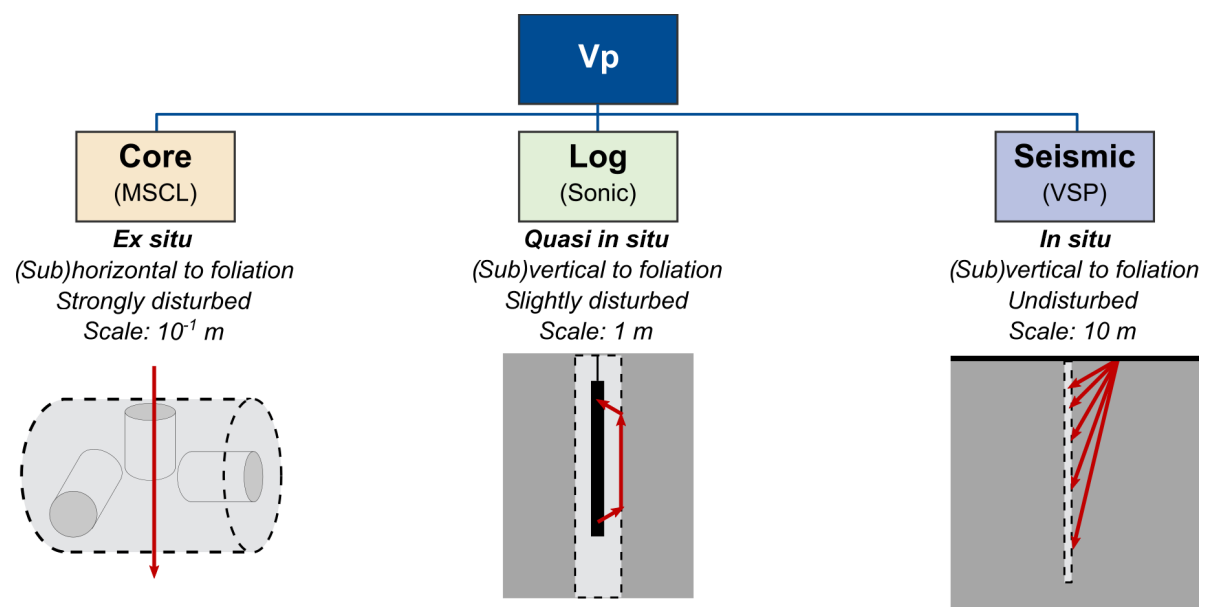

Figure 2. Schematic depicting the different environmental and measurement conditions of the core, log, and borehole seismic (VSP) P-wave velocity $(\mathrm{Vp})$ measurement. Arrows indicate the direction of seismic wave propagation.

extensive field campaigns providing physical properties from downhole logs and seismic profiles (Hedin et al., 2014, 2016; Krauß et al., 2015; Lorenz et al., 2015a; Simon et al., 2015). Together with the excellent core recovery and data availability, the COSC-1 drilling project constitutes a perfect case study to apply core-log-seismic data integration in a metamorphic environment.

\subsection{Geological background}

In the mid-Paleozoic, the Caledonian orogen formed during the continent-continent collision of Laurentia and Baltica (Gee et al., 2008). The Scandinavian Caledonides are composed of nappes that were thrusted over the Baltic platform margin accommodating several hundred kilometers of southeastward shortening. These thrust sheets are subdivided into the Lower, Middle, Upper, and Uppermost Allochthons, which rest on autochthonous crystalline basement (Fig. 1; Gee et al., 2008; Roberts and Gee, 1985). The Lower Allochthon is mainly composed of sedimentary rocks of Upper Proterozoic to Silurian age derived from the outer Baltoscandian margin (Gee et al., 2010). The Middle Allochthon consists of several nappes with an increase in metamorphic grade, derived from the outer to outermost Baltoscandian margin including the continent-ocean transition zone (Gee et al., 2013). The uppermost part of the Middle Allochthon comprises the Seve Nappe Complex (SNC). The SNC is divided into a lower part of similar protolith to the underlying (greenschist facies) Särv Nappes but is highly deformed in amphibolite and locally eclogite facies; a central part composed of granulite facies migmatites and paragneisses (e.g., Ladenberger et al., 2014), overlaid by an upper part of lowermetamorphosed sedimentary rocks (Gee et al., 2010). The Upper Allochthon is dominated by Early Paleozoic Iapetusderived sedimentary rocks, ophiolites, and volcanic arc complexes of greenschist facies. The Uppermost Allochthon is mostly composed of metasediments and carbonates from the Laurentian margin (Gee et al., 2008).

The dimension of the Caledonian mountain range and its formation mechanisms are similar to those of the more recently formed Himalayan orogen (Labrousse et al., 2010). Subsequent glaciation, tectonic uplift, and gravitational collapse left most parts of the mountain range deeply eroded exposing rock formations of middle to lower crust levels (Gee et al., 2008). Today's remnants, the Scandes, extend over a distance of about $300 \mathrm{~km}$ across the Scandinavian Peninsula, over a length of about $1700 \mathrm{~km}$, from the Norwegian Skagerrak coast in the south up to the North Cape. An extensive review of the Caledonian Orogeny and related areas is provided by Corfu et al. (2014) and Gee and Sturt (1985).

Along the COSC-1 borehole, based on the lithological descriptions of the cored rocks, four main sections were identified at depth (Lorenz et al., 2015a): (1) gneisses of varying compositions (mainly felsic, amphibolitic, calc-silicate), often garnet- and diopside-bearing, occur from the top to about $1800 \mathrm{~m}$; (2) an extensive (ductile shear) deformation zone prevails between 1800 and $2345 \mathrm{~m}$; followed by (3) a $15 \mathrm{~m}$ thick retrograde transition zone from amphibolite facies gneisses into lower-grade meta-sedimentary rocks; and (4) mylonitized quartzites and metasandstones of unclear tectonostratigraphic position that characterize the lowermost part to the bottom of the borehole at $2495 \mathrm{~m}$.

The potential to investigate the deep structure of the orogenic root from the surface is directly addressed in the COSC project. It generally focuses on the physical properties and inner structure of the emplaced nappe complex associated with high-grade metamorphic allochthonous rocks as well as the character and age of deformation of the underlying thrust sheets, the main Caledonian decollement, and the Precambrian basement (Gee et al., 2010; Lorenz et al., 2015a). 


\section{Data and methods}

For this study, we used compressional wave velocities from a multi-sensor core $\log$ (MSCL) and downhole data including a short-spacing sonic log (Lorenz et al., 2015b) and zerooffset vertical seismic profile (Krauß et al., 2015) from the COSC-1 borehole (see also Fig. 2). In addition, we measured selected core samples to provide seismic properties of characteristic lithological units. Based on these laboratory measurements, we calculated velocities at different environmental conditions (intrinsic, lithostatic pressure, and atmospheric pressure), which then served as a calibration tool for the core and downhole logging data. The individual data sets and experimental acquisition used for this study are described in the following subsections. Table 1 provides an overview of the individual measurements and related velocities and which nomenclature is used throughout this study.

\subsection{Laboratory measurements}

Laboratory analyses are routinely applied to study the elastic properties, fabric, and seismic anisotropy of crustal and mantle rocks (e.g., Barberini et al., 2007; Kern, 1982; Siegesmund et al., 1991; Zappone et al., 2000). We used seismic wave velocities measured in 16 core samples. These measurements were conducted at room temperature and varying confining pressure using the pulse-transmission method (Birch, 1960, 1961). In order to determine the seismic anisotropy, i.e., the directional dependence of seismic velocity compressional $(\mathrm{P})$ wave, the velocities were measured in three mutually perpendicular core plugs drilled out of each of the 16 core samples.

Six of these samples were measured by Wenning et al. (2016), chosen based on the most abundant lithologies derived from the lithological core description (Lorenz et al., 2015b). In order to extend and complement these measurements, we selected 10 additional samples at depth intervals and lithologies that were not previously covered (see Table A1 for a detailed sample list). In general, the 16 samples cover a large depth range of the borehole including potential zones of both higher and lower reflectivity as, for example, indicated by the zero-offset vertical seismic profile (Krauß et al., 2015).

The core samples were cut at lengths of about 15 to $20 \mathrm{~cm}$ from the COSC-1 drill cores. From each sample, we drilled three cylindrical core plugs of 3 to $5 \mathrm{~cm}$ length and $2.54 \mathrm{~cm}$ diameter (see also Fig. 2). The orientation of the plug axes $x$, $y$, and $z$ agree with the major structural axes that are defined by the sample's foliation and lineation and which we have determined by visual inspection. Following the common practice (Zappone et al., 2000), we designated $z$ as the axis normal to the foliation plane. The foliation plane is spanned by the $x$ and $y$ axes, where $x$ is oriented parallel and $y$ perpendicular to the apparent lineation. The core plug ends were cut and ground to plane-parallel surfaces in order to provide a good coupling with the signal transducers. The plugs were oven-dried at $100^{\circ} \mathrm{C}$ for at least $24 \mathrm{~h}$ in order to eliminate free water from the pore space.

The plug dimensions (length and diameter) and dry weight were determined using a micrometer caliper $( \pm 0.01 \mathrm{~mm})$ and precision balance $( \pm 1 \mathrm{mg})$, respectively. We used the average diameter and length of four successive readings to reduce possible errors due to surface irregularities. The matrix density of each core plug was measured using a Hegas pycnometer (type: AccuPyc II 1340). This is based on a precise volume measurement using the gas displacement method (Lowell et al., 2004, p. 326).

The experimental procedure was similar to the one described in Wenning et al. (2016). For each core plug, ultrasonic seismic velocities were acquired under different confining pressure using a hydrostatic pressure vessel and corresponding acquisition system (Fig. 3; Barblan, 1990). The setup consisted of two piezoelectric transducers (lead-zircon ceramics, $1 \mathrm{MHz}$ resonance frequency), transmitter, and receiver, which were placed on the core plug's cylinder faces. They were held in place by a shrink tube jacketing plug and transducers. Additional metal wires, tightly wrapped around the shrink tube, sealed the core plug to prevent any oil leakage into it (Fig. 3). The prepared core plug was mounted inside the vessel where the oil pressure was applied and controlled using a pneumatic compressor. The pressure was first increased in $50 \mathrm{MPa}$ steps, from 50 to $250 \mathrm{MPa}$, and then decreased in $30 \mathrm{MPa}$ steps, between 240 and $30 \mathrm{MPa}( \pm 2 \mathrm{MPa})$. At each pressure step, a wave generator connected to one of the transducers produced an input square signal $0.2 \mu$ s wide, with an amplitude of $30 \mathrm{~V}$, and a pulse rate of $0.5 \mathrm{kHz}$. Simultaneously, the wave generator sent a trigger signal with the same frequency to a PC-based wave analyzer. The analyzer used an impedance of $1 \mathrm{M} \Omega$ over a range of $\pm 500 \mathrm{mV}$. The waveforms were recorded with a repetition rate of $80 \mathrm{~ns}$ and a sampling rate of $100 \mathrm{MHz}$. The electric noise was minimized by averaging the tracks.

The measurements were calibrated using steel cylinders of varying lengths to correct for the delay in the observed travel times (i.e., $t_{\text {observed }}=t_{\text {rock }}+t_{\text {system }}$ ), which was caused by the cables, transducers, and interfaces in the electronic system. The calibration was conducted at confining pressures of 50 and $100 \mathrm{MPa}$. The system travel time $\left(t_{\text {system }}\right)$ was obtained by averaging the results from these two pressures.

We performed our measurements at room temperature (ca. $22^{\circ} \mathrm{C}$ ), which should be a good approximation of the in situ condition because of the very low geothermal gradient (ca. $20^{\circ} \mathrm{C} \mathrm{km}^{-1}$ ) and low temperatures observed at about $2500 \mathrm{~m}$, the bottom of the borehole $\left(T_{\log }<60^{\circ} \mathrm{C}\right.$; Lorenz et al., 2015b). Generally, seismic velocities decrease with temperature (e.g., Motra and Stutz, 2018; Schön, 1996). However, at very low temperatures $\left(<100^{\circ} \mathrm{C}\right)$, like we observe in the COSC-1 borehole, this effect can be neglected (Kern, 1978). Moreover, the measured pressure-to-temperature increment (about $1.5 \mathrm{MPa} \mathrm{K}^{-1}$ ) in the COSC-1 borehole is suf- 
Table 1. Overview of velocity nomenclature used in this study. The laboratory measurements were carried out on three mutually perpendicular core plugs. See text for details.

\begin{tabular}{llll}
\hline Velocity & $\begin{array}{l}\text { Type of } \\
\text { measurement }\end{array}$ & $\begin{array}{l}\text { Direction of } \\
\text { measurement }\end{array}$ & Description \\
\hline Vp0 & Lab & Triaxial & Intrinsic P-wave velocity based on laboratory measurements on core plugs \\
\hline VpAP & Lab & Triaxial & $\begin{array}{l}\text { P-wave velocity calculated at atmospheric pressure }(p=0.1 \mathrm{MPa}) \\
\text { based on laboratory measurements on core plugs }\end{array}$ \\
\hline VpLP & Lab & Triaxial & $\begin{array}{l}\text { P-wave velocity calculated at lithostatic pressure }(p=\operatorname{Sv}(z)) \\
\text { based on laboratory measurements on core plugs }\end{array}$ \\
\hline Core Vp & MSCL & Perpendicular to & $\begin{array}{l}\text { P-wave velocity continuously measured in whole cores using } \\
\text { a multi-sensor core logger }\end{array}$ \\
\hline Log Vp & Downhole sonic & $\begin{array}{l}\text { Parallel to borehole } \\
\text { axis }\end{array}$ & $\begin{array}{l}\text { P-wave velocity continuously logged downhole using a short-spacing } \\
\text { sonic sonde (Lorenz et al., 2015b) }\end{array}$ \\
\hline VSP Vp & Borehole seismic & $\begin{array}{l}\text { Parallel to borehole } \\
\text { axis }\end{array}$ & $\begin{array}{l}\text { P-wave velocities measured downhole using a zero-offset vertical } \\
\text { seismic profile (Krauß et al., 2015) }\end{array}$ \\
\hline
\end{tabular}

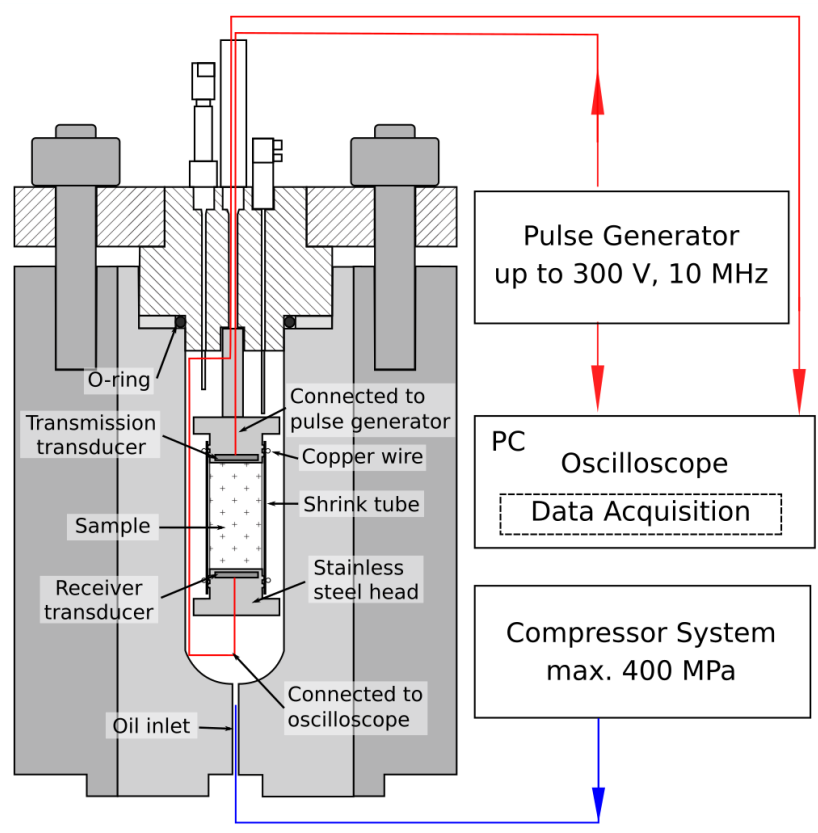

Figure 3. Schematic of the experimental setup used to determine the $\mathrm{P}$-wave velocities under confining pressure. This setup comprises a pressure vessel with a sample chamber, pulse generator, compressor control, and PC-based acquisition unit. Placed inside the oil-filled pressure chamber there is the sample assembly (based on Barblan, 1990).

ficiently high to prevent thermal microcracking (see Kern, 1990).

In the subsequent data processing, we calculated velocities and anisotropy coefficients as a function of confining pressure for each core plug and sample, respectively. Because of a very good signal quality, it was not necessary to ap- ply any additional filtering to the waveform data. First-arrival times were picked manually using a picking tool developed for this purpose (Grab et al., 2015). The seismic velocities were calculated using the plug length $L$, divided by the corrected travel time: $v=L /\left(t_{\text {picked }}-t_{\text {system }}\right)$. Changes in the plug length due to compression can be neglected for these rock types (Zappone et al., 2000).

We calculated P-wave velocities at atmospheric and at lithostatic pressure to relate to the different conditions of the velocity measurements from downhole sonic, MSCL, and borehole seismic data. The lithostatic pressure was calculated from the core and downhole logging density and is shown together for the associated sample depths in Fig. 4. Since density was only logged down to about $1600 \mathrm{~m}$, we used extrapolated densities down to $2500 \mathrm{~m}$ depth showing slightly higher pressures than those calculated from the core.

We used the relationship derived by Ji et al. (2007) to calculate P-wave velocity-pressure curves (Fig. 5) for each core plug of our 10 core samples. This relationship consisted of a four-parameter exponential equation to relate the measured velocities to confining pressure by solving a least-squares curve-fitting problem (Fig. 5). The intrinsic velocity (Vp0), which corresponds to the undisturbed, crack-free rock matrix, was calculated from the intercept of the extrapolated linear part of the velocity-pressure relation. The velocities at room pressure (VpAP, $p=0.1 \mathrm{MPa})$ and lithostatic pressure $(\mathrm{VpLP}, p=\mathrm{Sv}$ ) were determined from the non-linear representation of the velocity-pressure relation (Fig. 5).

Wenning et al. (2016) used a slightly different relation for their six samples, proposed by Wepfer and Christensen (1991). For most applications aiming to determine the linear high-pressure part and intrinsic anisotropy, both relations give consistent results. However, the inherent zero-boundary condition of Wepfer and Christensen's relation may lead to 


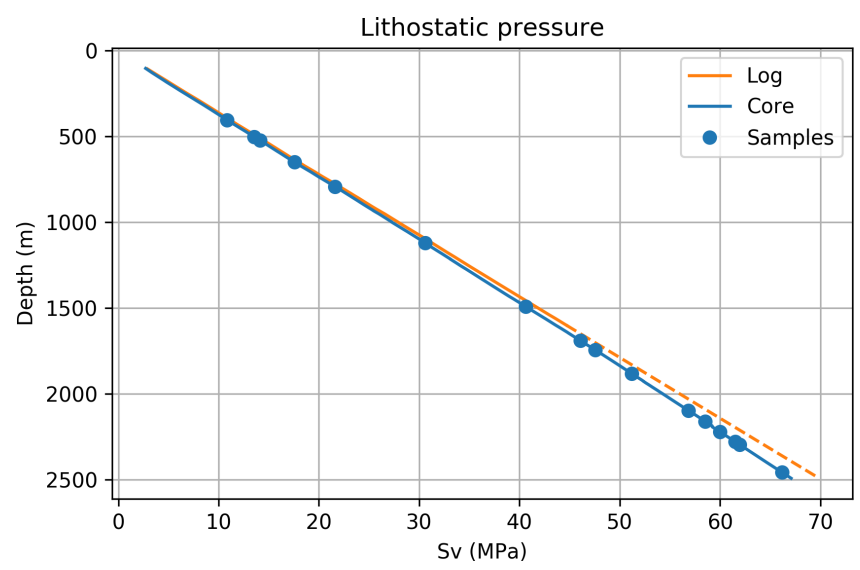

Figure 4. Lithostatic pressure curve of the COSC-1 borehole derived from core and downhole density measurements (Lorenz et al., 2015b). The values for the 16 core samples are marked accordingly. The dashed line was linearly extrapolated since downhole density was only logged down to about $1.6 \mathrm{~km}$.

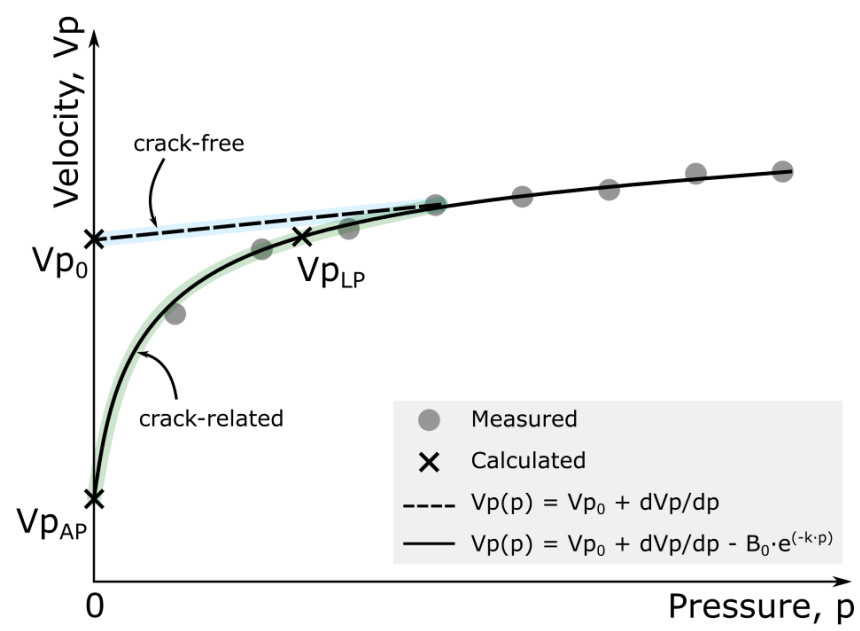

Figure 5. Schematic velocity-pressure relation depicting the measured and calculated seismic P-wave velocity $\mathrm{Vp}$ as a function of confining pressure $p$. Based on the best curve fit for the linear (dashed line) and non-linear part (solid line), velocities can be calculated under different environmental conditions: $\mathrm{Vp} 0$ - intrinsic velocity, VpAP - atmospheric pressure, VpLP - lithostatic pressure (adapted from Ji et al., 2007).

underestimated velocities in the extrapolated, non-linear lowpressure part, which is why we used the relationship by Ji et al. (2007) for our 10 samples, instead.

A full data example for one sample is shown in Fig. 6. It shows the measured P-wave velocities as a function of increasing and decreasing confining pressure for each of the three core plugs and the velocity-pressure curves calculated from the downgoing pressure cycles.

The intrinsic seismic anisotropy $(\mathrm{AVp})$ was determined from the $\mathrm{Vp} 0$ measured along the $x, y$, and $z$ directions (Fig. 6). In the literature there are different representations of the velocity anisotropy (Birch, 1961; Crampin, 1989; Schön, 1996). These representations are generally based on a fractional difference of the maximum and minimum measured velocities but distinguished in the applied denominator. We used a definition after Crampin (1989), which is described by the degree of the fractional difference of the maximum and minimum velocity of the rock sample; i.e., $\mathrm{AVp}=100 \times\left(\mathrm{Vp}_{\max }-\mathrm{Vp}_{\min }\right) / \mathrm{Vp}_{\max }$.

The main source of error in the determination of seismic velocity is the uncertainty in picking the first-arrival times. We estimated a typical uncertainty in the picking of the P-wave first arrivals with an upper limit of $\delta t_{\text {observed }} \cong$ $\pm 0.1 \mu$ s. The seismic velocity uncertainty was estimated using the concept of error propagation (e.g., Taylor, 1997), providing a measured $\mathrm{P}$-wave velocity uncertainty of $\delta \mathrm{Vp}=$ $\pm 0.11 \mathrm{~km} \mathrm{~s}^{-1}$ on average. The uncertainty propagation in the extrapolated velocities at zero confining pressure $(\delta \mathrm{Vp} 0)$ was based on the linear regression function that minimized the sum of the squared errors of the prediction. Subsequently, we used the error of the regression coefficients (i.e., slope and intercept) to derive the uncertainty for the anisotropy coefficient $(\mathrm{AVp})$ using the same approach as for the measured velocities. The uncertainty of the P-wave anisotropy was below $1 \%$ for all samples. Moreover, our error analysis has shown that the bulk uncertainty of the measured seismic velocities is dominated by the pick accuracy of the pulse arrival picks, while errors in the plug length only have a minor impact.

\subsection{Multi-sensor core $\log \mathrm{P}$-wave velocity}

Seismic P-wave velocity was measured every $5 \mathrm{~cm}$ on the $2.5 \mathrm{~km}$ COSC-1 cores using an MSCL (type Geotek MSCL$\mathrm{S}$ ), which is based on an automated full-waveform logging system (e.g., Breitzke and Spieß, 1993; Weber et al., 1997). The P-wave sensor setup comprised two signal transducers mounted on opposite sides, perpendicular to the core axis. The upper one was a motor-driven piston transmitter, while the lower one used a spring-loaded acoustic rolling contact (ARC), constantly pushed against the measured cores.

At each measuring position, a $230 \mathrm{kHz}$ P-wave pulse was sent from the transmitter through the core and was recorded by the receiver. The recorded signal was pre-amplified, digitized, and sent to the acquisition software at a sampling frequency of $12.5 \mathrm{MHz}$. The first-arrival times were determined using a threshold method providing a user-defined threshold level and time delay. This system automatically determined the first excursion above the given threshold, after the delay. The total travel time (TOT) was then taken at the first zerocrossing. During the acquisition procedure, the voltage level (amplitude), threshold level, and time delay were adjusted automatically, to ensure a good signal-to-noise ratio for the automatic picker. To provide a good coupling between the transducers and the core, the core surface was wetted before the measurement. 


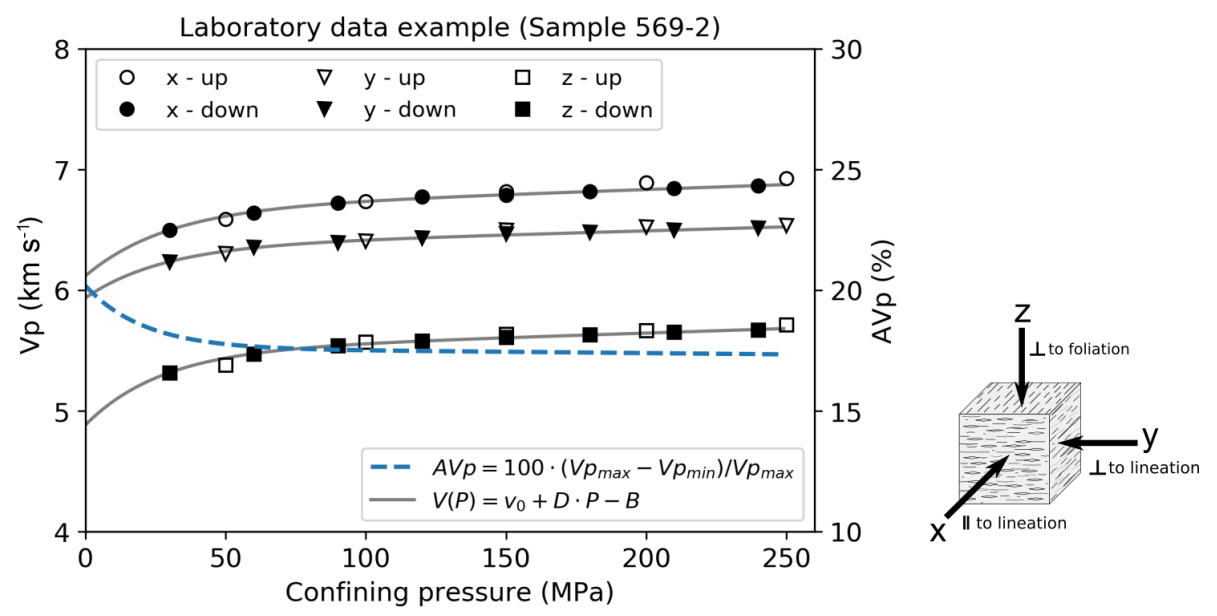

Figure 6. Data example showing confining pressure versus P-wave velocity (Vp) and anisotropy (AVp) for sample 569-2 (see Table 2). Open symbols refer to measurements during pressurization and filled symbols to measurements during depressurization. Different markers indicate the velocities measured in the respective $x, y$, and $z$ core plugs along the corresponding structural axes (see also Fig. 5 and text for details).

Furthermore, a calibration was carried out to determine the P-wave travel time offset (PTO), which accounts for the accumulated travel time delays through the transducer system (transducer faces, rubber plates, etc.). The actual travel time (TT) was derived by subtracting the PTO from total measured travel time, i.e., $\mathrm{TT}=\mathrm{TOT}-\mathrm{PTO}$.

The calibration based on travel times measured in wholeround and half-split POM (polyoxymethylen) cylinders of varying diameters (60 to $120 \mathrm{~mm}$ ), which were plotted and extrapolated by a best linear fit. The P-wave velocities were calculated using the corrected travel time TT and the nominal core diameter $(D=61$ and $47.6 \mathrm{~mm})$, by $\mathrm{Vp}=$ $D /(\mathrm{TOT}-\mathrm{PTO})=D / \mathrm{TT}$. No additional temperature correction was applied because the room temperature inside the laboratory was kept constant at about $21^{\circ} \mathrm{C}$.

\subsection{Downhole sonic logging}

A downhole sonic measurement was carried out as part of a complete downhole logging campaign in 2014, about 1 month after the drilling of the COSC-1 borehole was completed. The original data set is published by Lorenz et al. (2015b, 2019) and comprises, amongst other things, a density log and 3D core scan images. Downhole sonic velocities were continuously logged every $0.1 \mathrm{~m}$ by the Operational Support Group (OSG) of the ICDP using a standard full-waveform slimhole sonde (Antares, Germany). Transit times were calculated from first-arrival times, which first were picked automatically and then refined manually. The seismic P-wave velocities were calculated using the sonde's receiver spacing $(0.5 \mathrm{~m})$ divided by the transit time.

Based on refracted waves propagating along the borehole wall, the sonic log represents a vertical average velocity of the near-well vicinity over the receiver spacing. The investigation depth and resolved rock volume generally depend

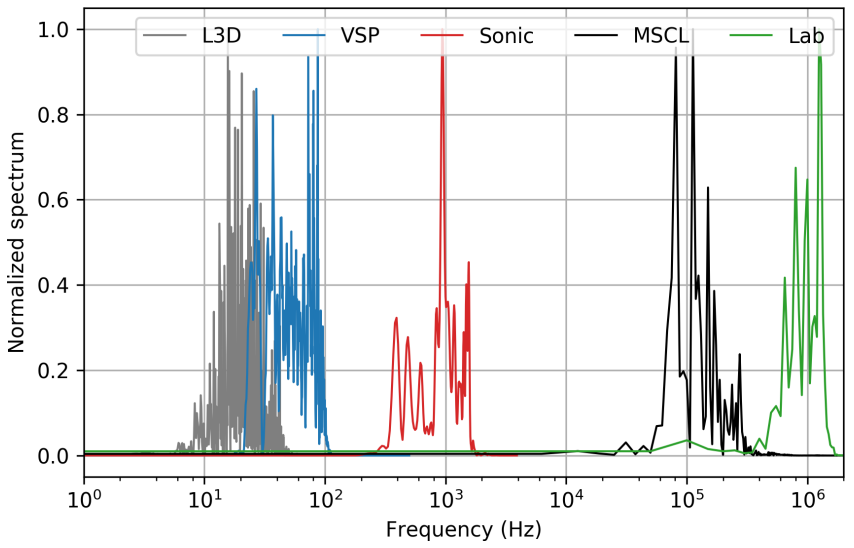

Figure 7. Comparison of frequency spectra of seismic measurements across multiple scales from limited 3D surface seismic (L3D), borehole seismic (VSP), downhole log (sonic), core measurement (MSCL), and laboratory samples (Lab). The downholerelated spectra are calculated from a single seismic trace and sonic waveform extracted from approximately the same downhole depth of about $500 \mathrm{~m}$.

on the formation velocities and frequencies and can be estimated by 3 times the dominant wavelength (Serra, 1984). The frequency range of the recorded sonic traces lies in the order of a few kilohertz (Fig. 7). For the given sonde geometry and nominal transmitter frequency $(20 \mathrm{kHz})$, the depth of investigation is about 0.75 to $1 \mathrm{~m}$. Thus, downhole logging velocities provide a good approximation of the in situ seismic velocities but can still be affected by micro-fracturing caused by drilling or steeply dipping natural fractures. 


\subsection{Zero-offset vertical seismic profile}

A zero-offset vertical seismic profile (VSP) was acquired in the COSC-1 borehole, as part of a comprehensive postdrilling seismic survey to image the SNC and its underlying formations (Krauß, 2017; Krauß et al., 2015). In our study, we used the P-wave velocities that were calculated by the first-arrival times of the consecutive downhole receiver stations. The receiver spacing was $2 \mathrm{~m}$ and the first-arrival times were smoothed by a 15 -point moving average ( $30 \mathrm{~m}$ interval) to account for small travel time variations.

For a zero-offset (or rig-source) borehole seismic, the direct P-wave ideally propagates downwards from the surface, parallel to the borehole. Thus, being relatively unaffected by the borehole itself, borehole-seismic velocities provide a good approximation of the vertical in situ seismic velocity of the borehole vicinity. The calculated, so-called interval velocity represents the constant velocity of the seismic wave traveling through a rock layer with a given interval thickness, which is defined by the applied receiver spacing $(2 \mathrm{~m})$. Thus, the distance over which the velocity is averaged is 4 times larger than for the downhole sonic $\log$ (at $0.5 \mathrm{~m}$ receiver spacing).

The signal frequencies ranged between 80 and $100 \mathrm{~Hz}$ (Fig. 7). The measurement scale was mainly dictated by the horizontal and vertical resolution. The former can be approximated by the first Fresnel zone of the dominant seismic wavelength. For the COSC-1 borehole range (0 to $2500 \mathrm{~m}$ ), this yielded an average horizontal resolution of about $300 \mathrm{~m}$ $\left(\lambda=75 \mathrm{~m}, v_{\text {const. }}=6 \mathrm{~km} \mathrm{~s}^{-1}\right)$. In contrast, the vertical resolution was about $20 \mathrm{~m}$, assuming one-quarter of the dominant wavelength (Rayleigh resolution limit).

\section{Results}

\subsection{Laboratory data}

The laboratory intrinsic seismic velocities lie between 5.9 and $6.9 \mathrm{~km} \mathrm{~s}^{-1}$ showing generally little scattering ( $\mathrm{SD}=$ $0.3 \mathrm{~km} \mathrm{~s}^{-1}$ ) throughout all samples (Table 2). The slowest velocities occur always along the $z$ axis, thus perpendicular to the foliation plane. Highest velocities occur in the foliation plane, i.e., along the $x$ and $y$ axes. The intrinsic seismic anisotropy exhibits a strong variation between $1 \%$ and $26 \%$, with an average error of $0.4 \%$. The average seismic anisotropy for all 16 samples is about $10 \%$ (Table 2).

Velocities calculated at lithostatic pressure show values between 4.8 and $6.8 \mathrm{~km} \mathrm{~s}^{-1}\left(\mathrm{SD}=0.5 \mathrm{~km} \mathrm{~s}^{-1}\right)$. Velocities calculated at atmospheric pressure are significantly lower, ranging from 1.5 to $5.7 \mathrm{~km} \mathrm{~s}^{-1}$ on average $(\mathrm{SD}=$ $1.3 \mathrm{~km} \mathrm{~s}^{-1}$ ). The measured sample densities vary between 2.7 and $3.1 \mathrm{~g} \mathrm{~cm}^{-3}$, with the highest densities observed for the amphibole-rich (mafic) samples (149-4, 193-2, 556-2, 631-1, and 661-3).

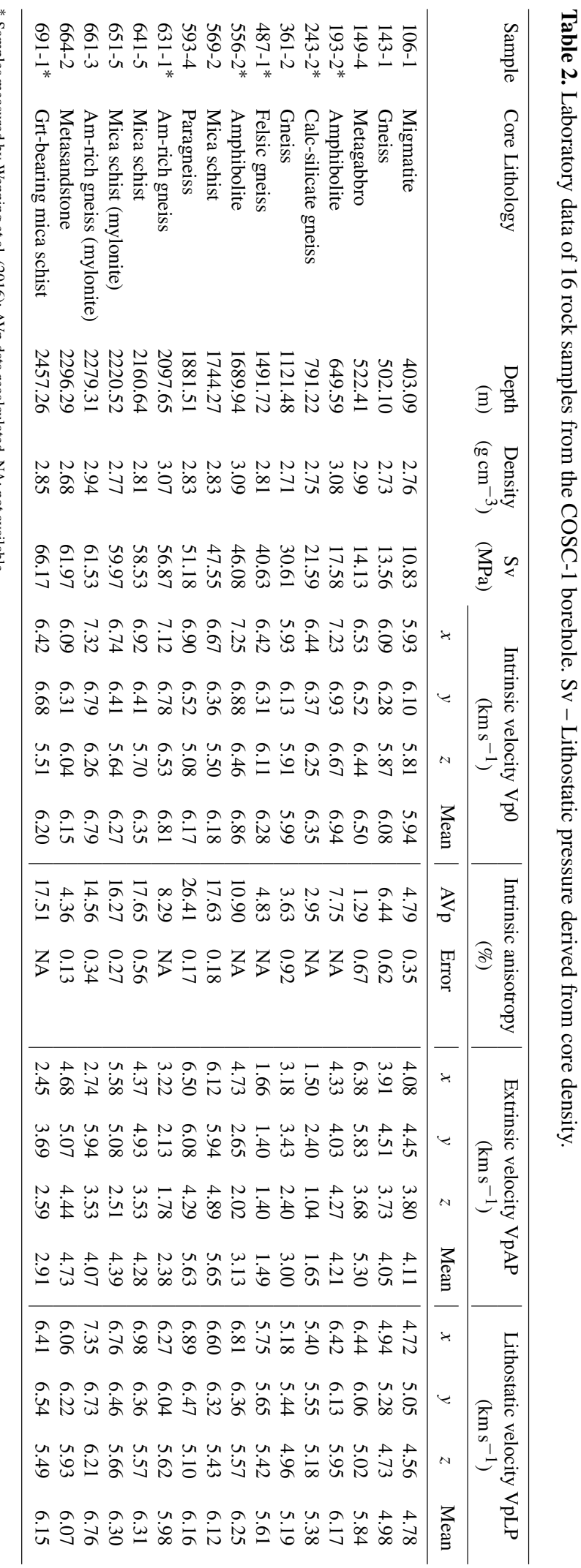




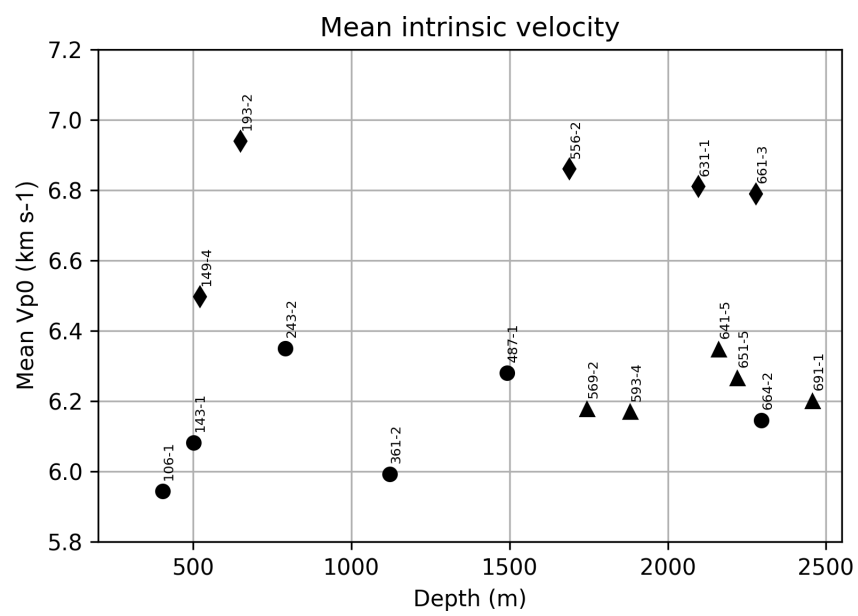

Figure 8. Mean intrinsic velocity measured in 16 core samples from the COSC-1 borehole plotted at the respective sample depth. Markers correspond to simplified lithological classes such as mafic amphibole-rich units $(\diamond)$, felsic gneisses and metasandstone $(\bullet)$, and mica schist $(\boldsymbol{\Delta})$. Note that the highest values occur for the mafic lithologies.

The mean intrinsic $\mathrm{P}$-wave velocities $(\mathrm{Vp} 0)$ were derived from the three-axial $(x, y$, and $z$ ) core plug measurements (cf. Fig. 6). These represent the most general case excluding any directional or structural effects and mainly account for the compositional effects (Fig. 8). Amphibole-rich (mafic) rock samples have velocities ranging between 6.5 and $6.9 \mathrm{~km} \mathrm{~s}^{-1}$, whereas all other more felsic rock samples including the felsic gneisses, mica schists, and metasandstone, are characterized by a $\mathrm{Vp} 0$ between 6.0 and $6.4 \mathrm{~km} \mathrm{~s}^{-1}$. The lowest $\mathrm{Vp} 0$ can be associated with the felsic gneiss samples, while the mica-rich schists show slightly higher Vp0. Moreover, both metasandstone (sample 664-2) and the carbonate-rich gneiss (sample 243-2) show very similar $\mathrm{Vp} 0$ as for the mica schists (e.g., samples 641-5, 651-5).

The seismic $\mathrm{P}$-wave anisotropy $(\mathrm{AVp})$ changes with increasing depth. This provides a simplified anisotropy-depth profile along the COSC-1 borehole (Fig. 9). The uppermost about $600 \mathrm{~m}$ show medium anisotropy $(<10 \%)$ and low values $(<5 \%)$ between 750 and $1500 \mathrm{~m}$. Between 1600 and $1900 \mathrm{~m}$, we observe the highest anisotropy effect with values up to $25 \%$, which decreases again, further below.

Comparing the different velocity distributions, the velocities at atmospheric pressure (VpAP) show very strong scattering and generally low values, agreeing well with the velocities measured in core under similar pressure conditions (Fig. 10). Velocities at lithostatic pressure (VpLP), in contrast, follow the in situ velocities measured downhole by the sonic and zero-offset VSP logs. On average, the intrinsic velocities $(\mathrm{Vp} 0)$ are slightly higher than those calculated under lithostatic pressure.

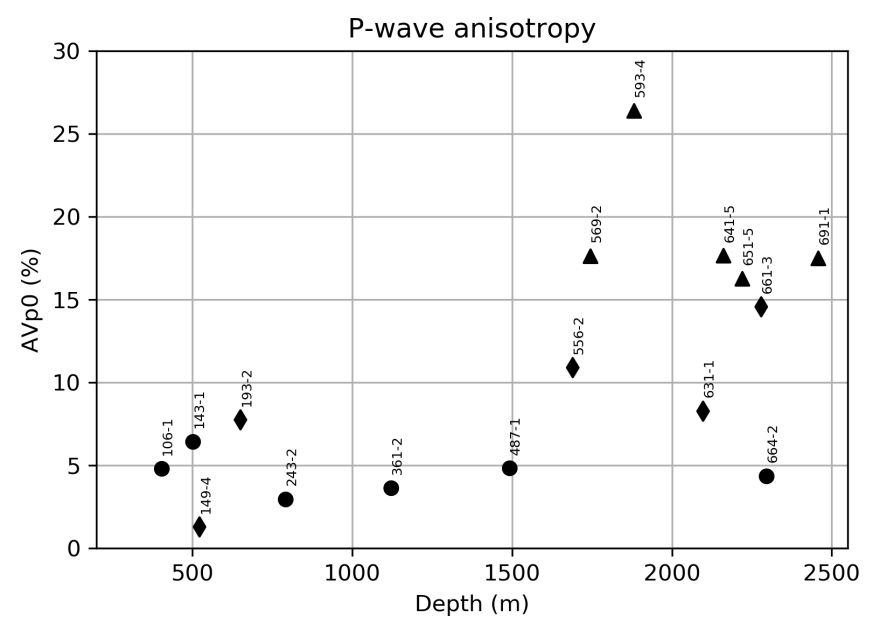

Figure 9. Seismic anisotropy measured in 16 rock samples from the COSC-1 borehole plotted at the respective sample depth. Markers correspond to simplified lithological classes such as mafic amphibole-rich units $(\diamond)$, felsic gneisses and metasandstone $(\bullet)$, and mica schist $(\boldsymbol{\Delta})$.

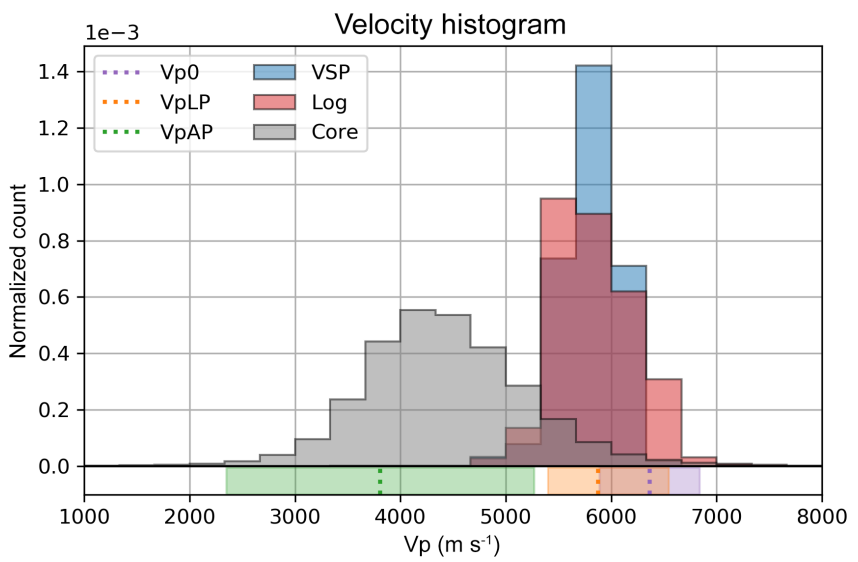

Figure 10. Distribution of $\mathrm{P}$-wave velocities derived from laboratory samples ( $\mathrm{Vp} 0, \mathrm{VpLP}, \mathrm{VpAp})$, core measurements (Core), downhole logging (Log), and borehole seismic (VSP). The sample velocities are displayed below the histograms indicating the mean and standard deviation of the 16 laboratory core samples.

\subsection{Lab, core, and log data integration}

Downhole sonic and VSP logs show a good correlation, while VSP velocities have a lower resolution caused by the averaging. The raw core velocities show a strong scattering and lower velocities on average (Fig. 10).

As we generally relate the core-derived data to measurements at surface conditions and the sonic and VSP logs to measurements under hydrostatic pressure in the borehole and the in situ rock (cf. Fig. 2), we expect the downhole measurements to show potentially higher velocities than those measured in core. Our data show that there is neither a clear correlation between core and downhole velocities nor an ob- 
servable static offset with depth (Fig. 11). There are places where the core-derived $\mathrm{Vp}$ increases, while the downholemeasured $\mathrm{Vp}$ decreases, for example in the lowermost $200 \mathrm{~m}$ of the borehole. Moreover, we can observe core velocities that closely approach or even exceed the downhole velocities (430 to $780 ; 1700$ to $2000 \mathrm{~m}$ ), while at other depth intervals $(620,1640$, and $1800 \mathrm{~m})$ core and downhole Vp mismatch significantly. Between 160 and $180 \mathrm{~m}$, we see a strong decrease in downhole P-wave velocities, which are likely related to a karstic unit previously recognized by a very high secondary porosity (Lorenz et al., 2015b). Here, the core and downhole velocities show good agreement.

From about 430 to $780 \mathrm{~m}$, we observe several peaks in the core velocities, which also correlate with peaks in the downhole velocity and density logs. Between 780 and $1900 \mathrm{~m}$ the core velocities gradually increase and they are accompanied by several smaller, less pronounced peaks, which often match with peaks in the downhole velocity and density logs (e.g., between 900 and 1000 m). From about 1900 m, down to about $2350 \mathrm{~m}$, the core velocities tend to decrease, before they increase again abruptly and clearly approach the downhole velocities. Zones of clear opposite trends in the core velocities and downhole or VSP logs can be seen, for example, at 200 to 240,600 to 625,1200 to 1250 , or 1625 to $1650 \mathrm{~m}$. These intervals encompass various core lithologies but most abundantly correlate with gneiss, calc-silicate rock, and amphibole gneiss.

In general, the superimposed mean sample velocities (intrinsic Vp0, atmospheric VpAP, and lithostatic VpLP) correlate well with the associated core (corresponds to VpAP) and downhole (corresponds to VpLP and $\mathrm{Vp} 0$ ) velocities. The sample densities match almost perfectly the core and downhole density measurements. While the mean intrinsic velocity $\mathrm{Vp} 0$ agree mostly with the downhole seismic velocities, they are slightly higher in some depth intervals (e.g., samples 193-2, 631-1), possibly due to anisotropy effects. The mean velocities calculated at lithostatic pressure (i.e., VpLP) are generally consistent with the downhole velocities and only show slightly lower values for samples 106-1, 143-1, 2432 , and 361-2, which are located above about $1600 \mathrm{~m}$. Below about $1700 \mathrm{~m}$, all samples (except sample 631-1) show very similar VpLP to the intrinsic velocities Vp0 (cf. Fig. 11, where markers are partly overlapped).

The velocities calculated at atmospheric pressure (i.e., VpAP) match the core velocities except for the samples 3612, 556-2, 631-1, and 691-1. For samples 243-2 and 487-1 the mean velocities at atmospheric pressure are exceptionally low $\left(1.7\right.$ and $\left.1.5 \mathrm{~km} \mathrm{~s}^{-1}\right)$ and thus outside the displayed value range (see also Table 2).

At about 1750 and $1880 \mathrm{~m}$, core and downhole velocities agree very well and the sample velocities (569-2 and 593-4) at atmospheric pressure are close to that at lithostatic pressure. Fracture mapping indicates a higher amount of lowangle fractures at these depths (Wenning et al., 2017). Moreover, these samples show the highest anisotropy values of all samples. We cannot observe any direct correlation of the foliation dips and the velocity data.

\subsection{Comparison of velocity data at core scale}

We conducted a detailed analysis of the measured seismic velocities at core scale (centimeter to millimeter), for six selected core sections (Fig. 12a-f), which represent characteristic lithological units with respect to their seismic properties. We compared the measured core and downhole velocities with the laboratory results and correlated them with the unrolled $360^{\circ}$ core scans (Lorenz et al., 2015b) of each selected core section. Missing core data are caused by samples taken previously from the core measurements.

Section 106-1 (Fig. 12a) is a migmatite unit that is characterized by an alteration of darker restite bands and leucocratic melts (chemically very similar to felsic gneiss). Both core and downhole velocities are relatively stable showing an average difference of about $1.6 \mathrm{~km} \mathrm{~s}^{-1}$. Sample velocities calculated at atmospheric conditions agree with the very low core $\mathrm{Vp}$. The lithostatic velocity, however, is lower than those logged downhole, whereas the intrinsic velocities are higher. This indicates a strong effect of microcracks with poor orientation. The intrinsic seismic anisotropy is comparably low $(<5 \%)$. Similar results were obtained for the gneiss sample (e.g., sample 143-1; cf. Fig. 11), which have slightly higher core velocities (ca. $4.5 \mathrm{~km} \mathrm{~s}^{-1}$ ) but similar downhole $\mathrm{Vp}$ (ca. $5.6 \mathrm{~km} \mathrm{~s}^{-1}$ ).

Section 193-2 (Fig. 12b) contains amphibolite where core and downhole velocities match well. We observe similar results for the metagabbro (sample 149-4, cf. Fig. 11), which are chemically almost equivalent. A fracture in the core section can be clearly identified by the core Vp. The velocities at lithostatic pressure match almost perfectly with the downhole velocity, whereas the velocities at atmospheric pressure are considerably lower than the associated core velocities. In comparison with the amphibolite sections, the metagabbro exhibits only slightly higher downhole velocities, which, however, still agree with velocities measured in core. In general, both units show very similar characteristics.

Section 361-2 (Fig. 12c) is dominated by gneiss of felsic composition and shows similar characteristics as the uppermost gneiss sections (e.g., sample 143-1; cf. Fig. 11) and slightly higher velocities, which possibly relates to an increase in mafic minerals such as amphibole. The core and downhole Vp differ strongly by up to $2 \mathrm{~km} \mathrm{~s}^{-1}$. The downhole velocities lie around $6.2 \mathrm{~km} \mathrm{~s}^{-1}$. A small amphibolite layer ( $<5 \mathrm{~cm}$ in thickness) can be well resolved by the core velocity. The core and downhole velocity of the surrounding gneiss unit agree well with the atmospheric velocity (VpAP) and the intrinsic velocity $(\mathrm{Vp} 0)$, respectively.

Section 569-2 (Fig. 12d) contains mostly mica schist. It exhibits the strongest anisotropy (15\% to $20 \%)$ of the cored rocks (see also Fig. 9). The core velocities (ca. 5 to $5.5 \mathrm{~km} \mathrm{~s}^{-1}$ ) generally agree with the downhole velocities (ca. 


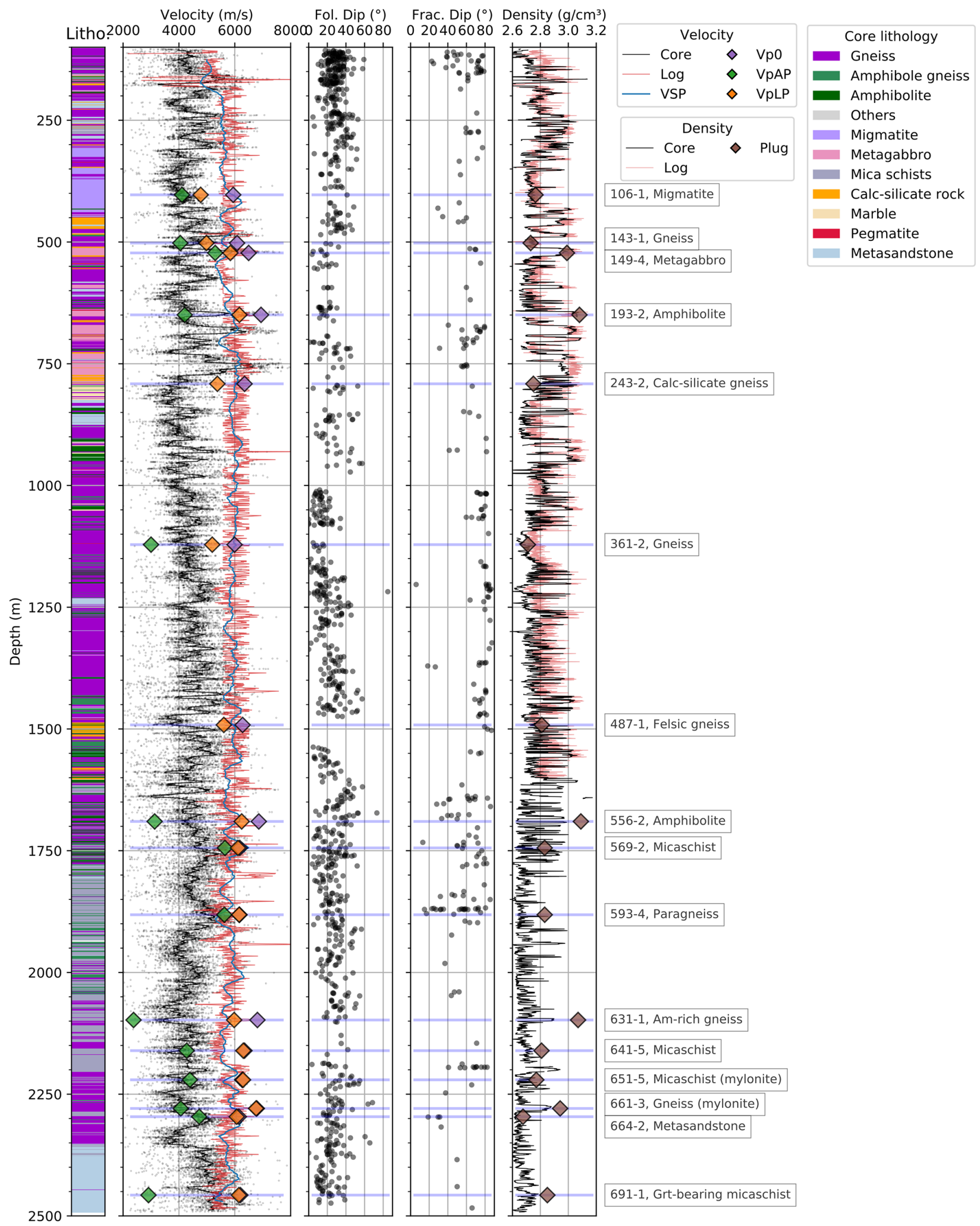

Figure 11. Core-log data integration of the seismic properties alongside with the fracture and foliation dips (Wenning et al., 2017) in the COSC-1 borehole. The sample velocity and density data are superimposed on the respective log panels. The lithology is based on the COSC-1 lithological description of the core (modified after Lorenz et al., 2015b). VSP velocities are based on the zero-offset vertical seismic profiling data (Krauß et al., 2015). 
(a)

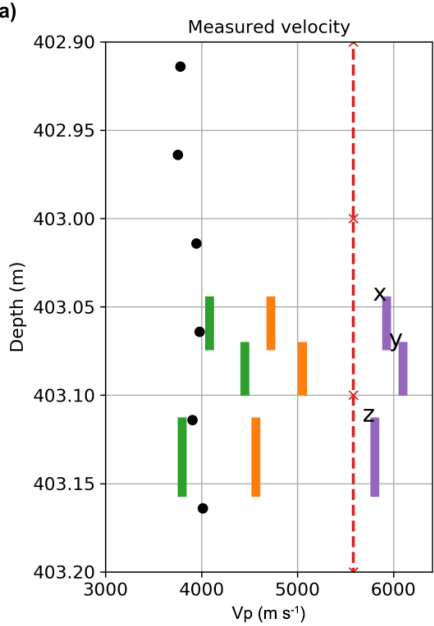

(c)

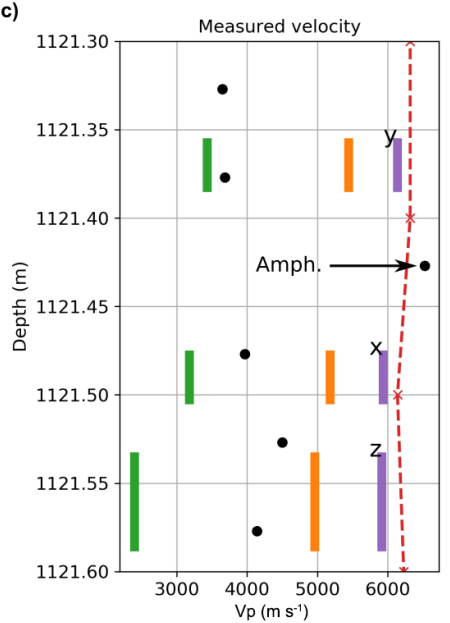

(e)

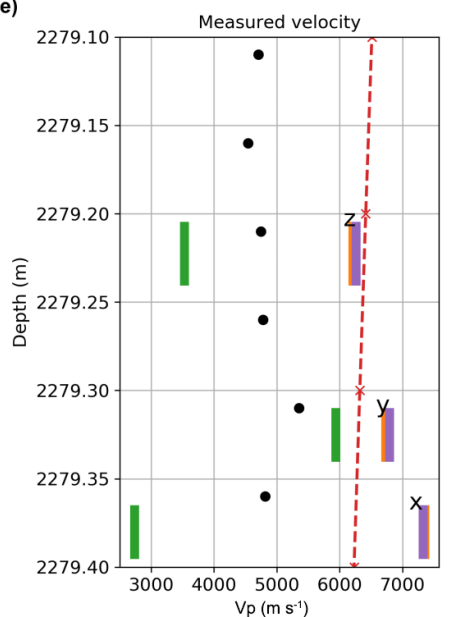

Core 106-1

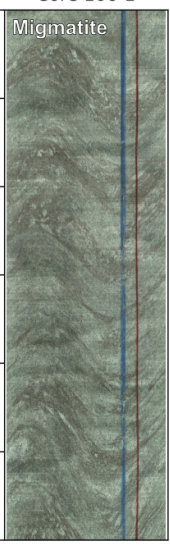

(b)
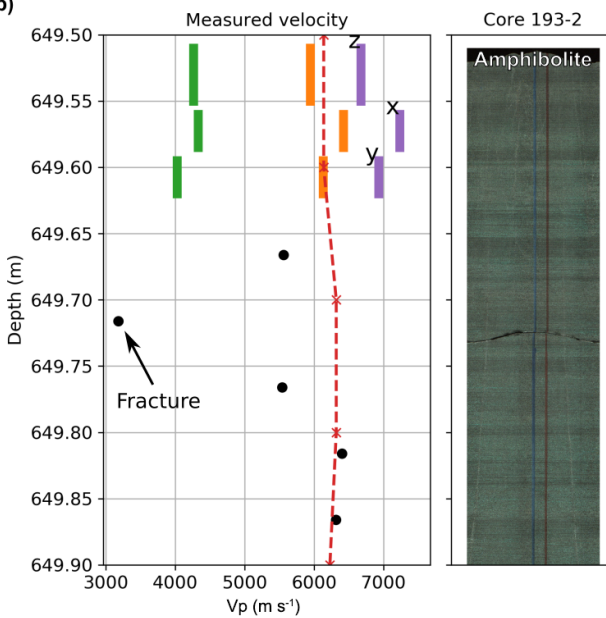

(d)
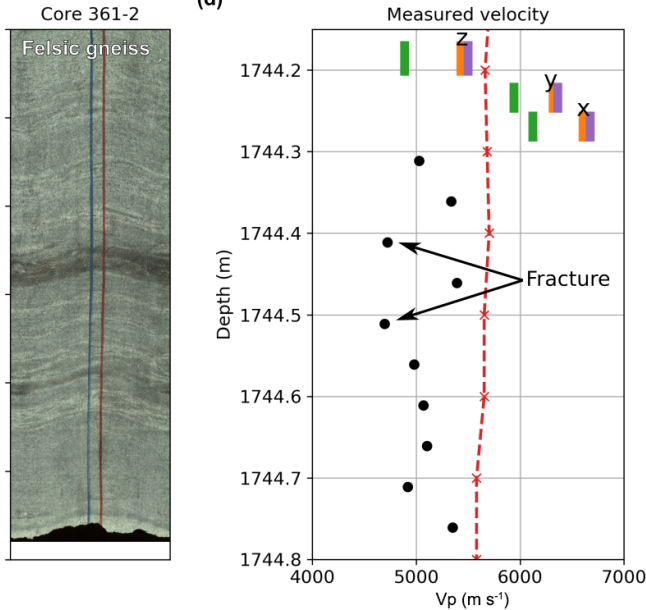

Core $569-2$
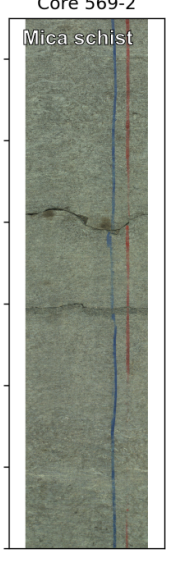

Core 661-3

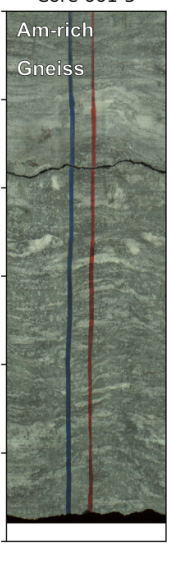

(f)

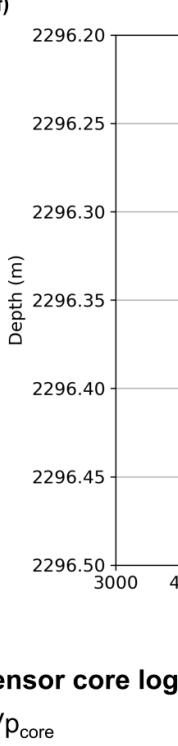

Core 664-2

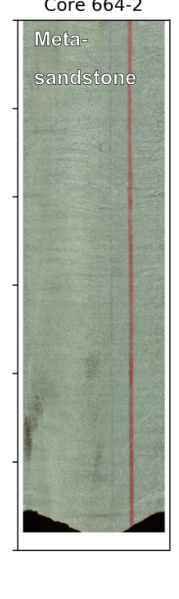

\section{Core plug \\ Multi-sensor core log \\ VpAP $=$ VpLP $=$ Vpo \\ ••..• V $V p_{\text {core }}$ \\ Downhole sonic log \\ $--x--p_{\log }$}

Figure 12. Comparison of P-wave velocities across different scales. (a-f) Laboratory sample, core measurements, and downhole sonic velocities are shown next to the unrolled, true-color core scans. The colored bars represent the location of the three plug locations: black dots - core velocity from MSCL; red dashed line - downhole sonic velocity. The blue and red lines on the core images are common practice to indicate the top and bottom of the core. 
$5.5 \mathrm{~km} \mathrm{~s}^{-1}$ ), being only slightly lower. The horizontal $(x, y)$ plug velocities at atmospheric pressure are even higher than the downhole velocities and the vertical $(z)$ plug velocity at lithostatic pressure. However, the core velocities are still lower than the downhole velocities.

The amphibole-bearing gneisses of section 661-3 (Fig. 12e) have relatively low core velocities of about $4.8 \mathrm{~km} \mathrm{~s}^{-1}$. In contrast, the downhole velocities are very high $\left(6.4 \mathrm{~km} \mathrm{~s}^{-1}\right)$, which agree well with the vertical $(z)$ plug velocity at lithostatic pressure. The plug velocities at atmospheric pressure scatter strongly around the core velocities.

The metasandstone section 664-2 (Fig. 12f) is characterized by a very homogenous rock matrix and is predominately composed of quartz. The velocity anisotropy is very low $(<5 \%)$. Both atmospheric and lithostatic velocity match the corresponding core and downhole measurements well. The present velocity differences are likely caused by microcracks, as indicated by the sample velocities. The core velocities for this section are almost constant ( 4.5 to $4.8 \mathrm{~km} \mathrm{~s}^{-1}$ ), slightly higher than those measured in the uppermost felsic gneisses (see, e.g., section 361-2 in Fig. 12c).

\section{Discussion}

\subsection{Laboratory seismic properties}

Our laboratory investigations show that not only composition but also structural characteristics of the COSC-1 cores have a strong impact on seismic properties. Pechnig et al. (1997) showed that the physical properties of metamorphic rocks can be classified by both structure and composition. We have shown that samples from mafic rocks have average velocities higher than $6.5 \mathrm{~km} \mathrm{~s}^{-1}$ and densities above $2.9 \mathrm{~g} \mathrm{~cm}^{-3}$, whereas felsic gneisses and mica schists show lower P-wave velocities and densities of 2.7 to $2.8 \mathrm{~g} \mathrm{~cm}^{-3}$ (Table 2, Fig. 8). These results fit well with the characteristics observed on felsic and mafic rocks from the German Deep Drilling Program KTB (Bartetzko et al., 2005; Pechnig et al., 2005). We suggest that velocity contrasts mainly occur between the denser amphibole-rich units and the more felsic units including felsic gneisses, mica schists, and metasandstones.

Nevertheless, the mean intrinsic seismic velocity cannot clearly distinguish all investigated rock types probably because of very similar matrix velocities and rock compositions. Our results show that the P-wave seismic anisotropy provides additional information about the structural characteristics, which qualitatively correlates with the degree of foliation. We observed the highest anisotropy (>15\%) for the mica schists, which are characterized by a well-developed schistosity. In contrast, felsic gneisses and metasandstone samples showed a low anisotropy of about $5 \%$ or below. This suggests a strong structural dependence of the seismic veloc- ities for the rocks of the Lower Seve Nappe drilled by the COSC-1 borehole.

Assuming that the point measurements sufficiently represent the core, we distinguished four different zones based on the anisotropy depth profile (Fig. 9). They correspond to the following major lithological units: (1) medium-low $\mathrm{AVp}$ of alternating, very heterogeneous rock units (samples 106-1, 143-1, 149-4, and 193-2; 400 to $650 \mathrm{~m}$ ), (2) very low $\mathrm{AVp}$ of felsic rocks with low schistosity (samples 243-2, 3612, 487-1; 790 to $1500 \mathrm{~m}$ ), (3) high $\mathrm{AVp}$ of mica-rich rocks with well-developed schistosity (samples 569-2, 593-4, 631$1,641-5,651-5$, and $661-3 ; 1690$ to $2220 \mathrm{~m}$ ), and (4) low $\mathrm{AVp}$ of granofelsic quartz-feldspar-rich rocks (sample 664$2,>2280 \mathrm{~m}$ ). The lowermost depths were also not well constrained, being covered by only two samples: one metasandstone and one mica schist. According to the core description, however, most of the deepest $(>2200 \mathrm{~m}$ ) rock units are described as metasandstones with only a few layers of mica schist (Lorenz et al., 2015b). The presented anisotropy-depth profile (Fig. 9) is limited in resolution by the low number of samples. Despite large data gaps, we are able to divide the borehole into structural units that are not detectable based on other seismic properties.

Rocks of the Seve Nappe Complex were subject to high- to ultrahigh-pressure metamorphism (Arnbom, 1980; Klonowska et al., 2017; Majka et al., 2014), involving both structural and compositional changes of the protolith. Metamorphism may affect differently the seismic properties depending on the $p-T$ history. Generally, we assume an increase in seismic velocity with increasing metamorphism due to compaction and formation of denser minerals. On the other hand, seismic anisotropy at rock scale can either increase or decrease with increasing metamorphism due to crystallographic preferred orientation and dynamic recrystallization of constituent minerals under variable stress and temperature conditions (Bezacier et al., 2010; Falus et al., 2011; Keppler et al., 2017). We observed that for the upper $1.6 \mathrm{~km}$ of the COSC-1 borehole, the seismic anisotropy is lower for the high-grade gneisses and amphibolites, while at greater depths $(>1.6 \mathrm{~km})$ high anisotropy is associated with lowergrade mica schists (Figs. 11, 12).

Laboratory studies (e.g., Babuska and Cara, 1991; Kern and Wenk, 1990; Shaocheng and Mainprice, 1988) have shown that seismic anisotropy can be affected by the degree of deformation, such as associated with high-strain rates and the mylonitization of rocks. Because of the associated lineation or stretching of minerals, this can favor an increase in the seismic anisotropy, as we observe, for example, for the amphibole-rich gneiss sample (sample 661-3, Fig. 9). However, from the core or log velocities alone, we are not able to find strong evidence for a shear zone interface or zones of mylonitic deformation. Better constraints of the effects of tectonic deformation at the sample scale require additional analysis of the microstructure and related anisotropy. 


\subsection{Seismic velocities under laboratory and in situ condition}

We used sample velocities measured at increasing confining pressure using a hydrostatic pressure vessel (Fig. 3) to simulate velocities measured under atmospheric and downhole conditions. Based on velocity-pressure curves (Fig. 6), we calculated velocities that represent either intrinsic, core, or downhole logging conditions (Fig. 10).

For the uppermost samples, we observed higher intrinsic velocities than velocities calculated at their lithostatic pressure (Fig. 11). This is counterintuitive because we would assume that the velocities calculated at lithostatic (i.e., in situ) pressure are higher or at least similar to those calculated at zero confining pressure. If this is not the case, the calculated lithostatic pressure is not high enough to exceed the nonlinear (crack-related) part of the velocity-pressure relation. This implies that the in situ velocities for these rocks are more strongly influenced by fractures or microcracks than the velocities of samples at greater depth in the borehole.

Both core velocity and core density, which we used to calculate the lithostatic pressure, were measured under dry-rock conditions. If compared with in situ measurements, the effect of (partial) saturation could explain why velocities are lower than under in situ conditions (e.g., Kingdon et al., 1998). However, Fountain (1976) showed that this effect should be negligible in crystalline rocks with low porosity such as those in this study. Very similar density values from the core and downhole measurements (Fig. 4) supports that water saturation does not have a big impact.

To simulate velocities under in situ pressure conditions, we calculated velocities at their lithostatic pressure (Fig. 4). This assumes that the principal stresses are equal in all directions and determined only by the overlying rock masses (e.g., Zang and Stephansson, 2010). But the in situ stress field can be more complicated due to tectonic processes such as ridge push, post-glacial relief, or mantle-driven stress. For the COSC-1 area, the in situ stress anisotropy is low (Wenning et al., 2017). Thus, we assume that lithostatic pressure is a good approximation for the in situ pressure conditions. This is further confirmed by the good correlation between the mean velocities for 12 of the investigated 16 samples at lithostatic pressure and the downhole logging velocities (cf. Figs. 10, 11).

Low mean velocities at atmospheric pressure for some of the samples (Fig. 11: 361-2, 556-2, 631-1, and 691-1) could result from very low velocity in either one of the associated core plugs. This may result from insufficient data coverage of the low-pressure part of the velocity-pressure relation (cf. Fig. 5) causing wrong data extrapolation. Another source for such misfits is the different pressure relation used for the samples investigated by Wenning et al. (2016). This was based on the velocity-pressure relationship proposed by Wepfer and Christensen (1991). This empirical relationship is adequate at higher pressures but not for zero confining pressure. Thus, velocities calculated at atmospheric pressure are generally too low.

We infer that the observed difference between intrinsic velocity and those calculated at lithostatic pressure is mainly caused by microcracks induced by anisotropic stress relaxation after coring downhole (e.g., Wolter and Berckhemer, 1989). Due to the insufficient closure of microcracks the onset of the linear part of the velocity-pressure curve is shifted to higher ( $p>70 \mathrm{MPa}$ ) confining pressures, whereas the calculated lithostatic pressure is located in the non-linear part. The fact that this effect mainly occurs in the uppermost, less schistose samples (e.g., 143-1, 361-2) suggests that these samples are more affected by microcracks and that in the schistose samples microcracks are more aligned and therefore can close faster under increasing pressure.

Our results suggest that the intrinsic seismic velocities are a good representation of the in situ seismic velocities as measured by downhole logging. Although the velocities calculated at lithostatic pressure generally agree with the downhole velocities, the insufficient closure of microcracks result in lower values for the felsic gneiss units.

\subsection{Characteristics of core and downhole logging $\mathrm{Vp}$ measurements}

Core and downhole velocity measurements using MSCL and sonic tools, respectively, are subject to different scales, sensor setup, and environmental conditions (Fig. 2). Other studies have shown that differences in seismic properties are generally due to depressurization and formation of microcracks after the core extraction (e.g., Wolter and Berckhemer, 1989; Zang et al., 1989). Especially in sedimentary rocks, the mechanical rebound of pore spaces due to decompression is a primary correction factor when comparing core to in situ data (Urmos et al., 1993). For crystalline, metamorphic rocks, the effect of volume expansion is relatively small. Microcracks can be either randomly distributed or show a preferred orientation relative to the rock microstructure or to the stress field around the borehole (Dresen and Guéguen, 2004; Nur and Simmons, 1969). Our simulation of velocities under crack-related and crack-free conditions (Fig. 5) indicates a strong influence of microcracks and a significant crack-induced anisotropy for certain rock samples (e.g., Fig. 12a). This suggests that velocities measured in cores at atmospheric pressure are strongly affected by microcracking.

Figure 11 illustrates the significant differences between the core and downhole seismic velocities at several depths. The discrepancy between the core and downhole logs can have different reasons. As discussed above, the decompression of the cores causes the formation of microcracks (asymmetric strain relaxation). With respect to the sample lithology (Table 2), we observe the strongest mismatch and lowest core velocities for the gneiss units. For the metasandstones, mica schists, and mafic rocks the mismatch is comparably low and core velocities are increased. Especially, between about 450 
and $800 \mathrm{~m}$, core and downhole velocities matched very well, which coincides with mafic lithologies, i.e., metagabbros, amphibolites. These have higher densities, but they are probably also less affected by microcracks. We infer that microcracks impact the core velocities of the felsic gneisses more than other lithologies. Despite the general mismatch in the core and downhole velocities, the core velocities resolve both large-scale and small-scale (less than about $5 \mathrm{~cm}$ ) lithological changes that are related to mafic rocks (e.g., Fig. 12c).

Other effects on the measured core velocities can be related to structural characteristics like the presence of dipping foliation, natural fractures, and grain boundary orientations. We show that MSCL measurements are sensitive to fractures in the rock resulting in velocities that are too low (see Fig. 12b, d). Beside some naturally occurring fractures (see fracture column in Fig. 11; Wenning et al., 2017), most fractures are due to core handling, and there are of course those that occur inevitably between each core section. In total, natural fractures and core section transition zones account for only about $10 \%$ of the raw core data set suggesting that they are not the reason for the general mismatch. This is supported by the smoothed core velocities, where all such outliers were potentially removed (Fig. 11, smoothed core Vp profile).

The core data, unlike the downhole logging data, were acquired perpendicular to the core axis and, thus, parallel or sub-parallel to the metamorphic foliation (Fig. 2). In the presence of a well-developed foliation this would cause higher core velocities in horizontal direction, parallel to the foliation, as shown by our laboratory results where the fastest velocities always occur parallel to the foliation plane. However, at core scale and atmospheric pressure, this effect is less eminent and is only observed where a strong schistosity is present (Fig. 12d).

The core and borehole velocity measurements were carried out using different frequencies ranging from a few $100 \mathrm{~Hz}$ for the VSP data to up to $1 \mathrm{MHz}$ for the sample analyses (Fig. 7). In general, P-wave velocity and anisotropy dispersion may occur in porous and fractured rocks (Galvin and Gurevich, 2015; Thomsen, 1995). In the absence of a fluidsaturated, equant porosity as in the case of mostly crystalline metamorphic rocks, P-wave dispersion can generally be neglected. Moreover, the different frequency scales are closely linked to the investigated rock volume, i.e., with increasing signal frequency the investigated rock volume generally decreases.

The seismic properties show considerable changes between each data set (Fig. 13). Despite no strong correlation between the core lithology and measured seismic velocities (cf. Fig. 11), we can observe some characteristic zones (Fig. 13) in the velocity profiles that can be linked to a general trend in the lithology and which are consistent with the zones indicated by the anisotropy-depth profile as discussed earlier. Most eminent is the transition between the mafic, amphibole-rich rocks and the felsic gneisses at around 750 to $800 \mathrm{~m}$. Overlying mafic units can be traced across all scales indicated by strong velocity contrasts and peaks between 400 and $800 \mathrm{~m}$ due to the layering of mafic and felsic rock units. In the MSCL data we can associate the low velocities with felsic gneisses, whereas the mica schists and metasandstones show slightly increased core velocities. While the differentiation of mica schists and gneisses is very difficult due to the similar seismic velocities, high anisotropy values give indications of a unit dominated by mica schists, which also agrees with the lithological core description. This implies that the core-derived velocities cannot easily be used for core log seismic integration, both because they resolve the velocities at much greater resolution and because (in the case of the MSCL data) they are too low due to decompression.

Core and log velocities suggest that velocity contrasts in the Lower Seve Nappe are mainly related to the mafic rock units, which are can be associated with boudinaged amphibolites (Hedin et al., 2016) or dolerite intrusions (Juhlin, 1990). We conclude that these mafic units predominately occur in the uppermost $800 \mathrm{~m}$, in thick bands of 10 to $80 \mathrm{~m}$, exhibiting intermediate intrinsic anisotropy of up to $8 \%$. Potentially the core velocities can be used to derive a high-resolution reflectivity series with a high contrast level (dynamic range), which could help to better localize the origins of seismic reflections related to mafic units such as amphibolites and metagabbros.

Other studies in similar environments are, for example, by $\mathrm{Ji}$ et al. (2007), who focused on mafic or ultramafic rocks and orthogneisses from the Chinese Continental Scientific Drilling (CCSD) project in the Dabie-Sulu ultrahighpressure metamorphic terrane. They also showed a strong effect of microcracks caused by depressurization of the core material. Moreover, one can find a similar facies classification in terms of seismic velocities and anisotropy, where granitic gneisses exhibit lower $\mathrm{Vp}$ and $\mathrm{AVp}$ values than the ultramafic rocks. However, a direct comparison is only limited because they do not investigate lower-grade metamorphic rocks such as mica schists. Another study on the Iberian Peninsula (Zappone et al., 2000), of two main metamorphic complexes (Nevado Filabride and Alpujharride), was an attempt to reconstruct a transect across a continental crust (from upper or middle to lower levels) using samples representative of lithologies of various composition and metamorphic facies from outcrops. The exposed crust in that region of southern Spain, from Marbella to Ronda, shows a comparable large variability of rock types and an abundant component of high-temperature metamorphic rocks (up to migmatites). In contrast to the COSC-1 study, the Iberian study was conducted on outcrops, with rocks that went through an exhumation history up to exposition to atmospheric conditions (not the case in COSC-1). Moreover, most of the transect of the Alpujharride was representative of continental lower crust at the transition to the upper mantle, while in COSC-1 the rocks are of middle to crustal levels, i.e., only a few samples of the investigated units are compatible with the metamorphic conditions of the Seve Nappe. 

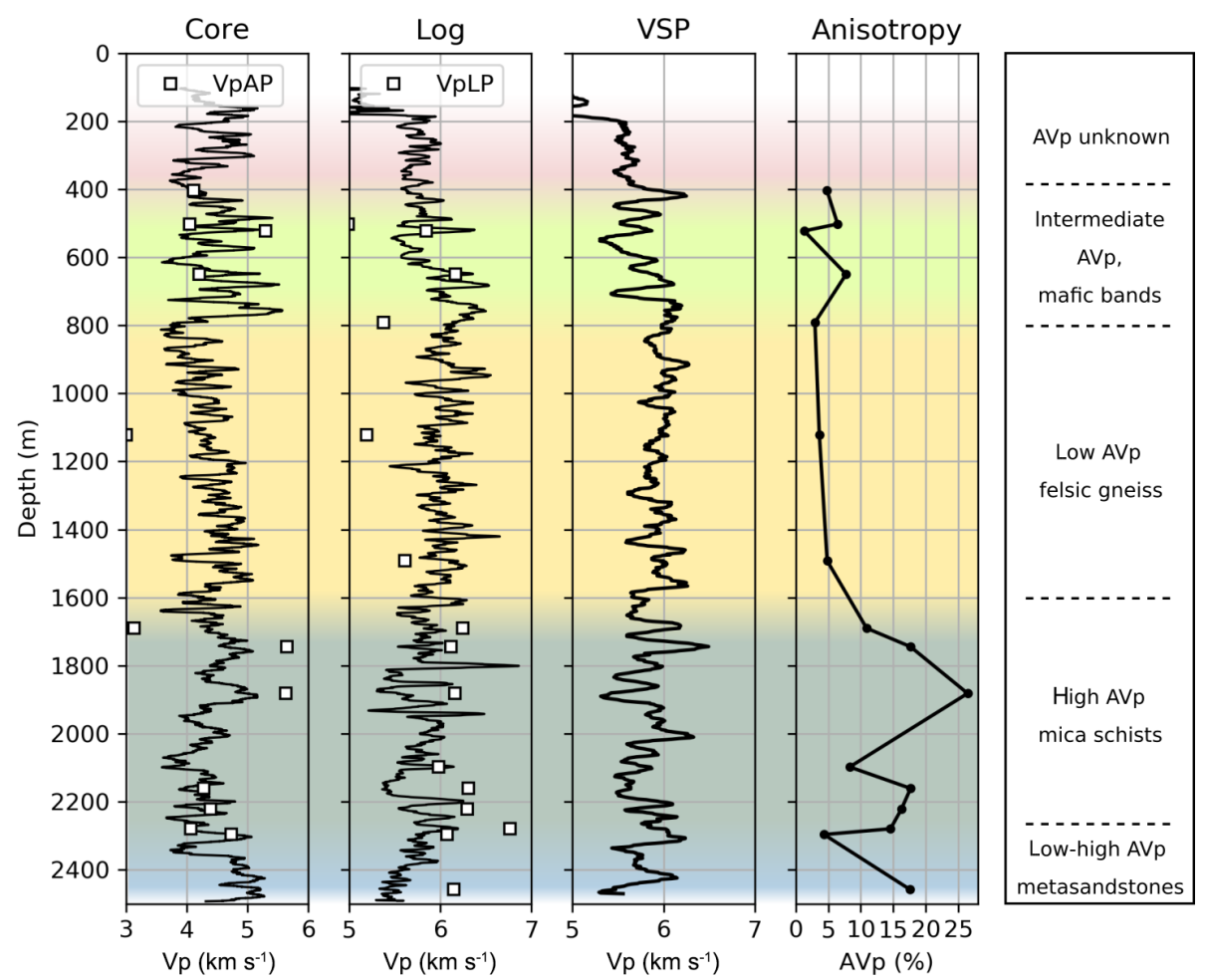

Figure 13. Upscaled core, log, and borehole seismic (VSP) velocities together with the laboratory-derived anisotropy-depth profile. Core and downhole logging velocities are smoothed over a $10 \mathrm{~m}$ average and superimposed by the mean sample velocities (markers) calculated at atmospheric (VpAP) and lithostatic (VpLP) pressure. The anisotropy profile is linearly interpolated (see also Fig. 9). The colored sections highlight characteristic velocity zones based on the resultant data sets shown here.

Thus, our results provide a valuable extension to the database of rock properties from different metamorphic facies.

\section{Conclusion}

Integrating seismic properties from laboratory samples and core and downhole data helps to better define and distinguish seismic characteristics of the COSC-1 lithology. Our comparison of seismic velocity measurements across multiple scales, from laboratory to field, show that seismic P-wave velocities measured in cores can partly resolve in situ lithological variations. These are, however, not only influenced by compositional changes but also overprinted by metamorphic foliation and microstructures.

The investigated seismic properties allow us to distinguish between at least three characteristic lithological units of the COSC-1 borehole: amphibolite or metagabbros, mica schists, and felsic gneisses. Although core velocities are affected by microcracks, they are able to resolve small-scale features such as thin mafic layers $(<5 \mathrm{~cm})$ or subhorizontal fractures. We were able to identify mafic units such as amphibolite by peaks in both core and downhole data, which can be used for lithological classification. Less prominent velocity contrasts but outstanding anisotropy values were observed for mica schists and metasandstones. Core and downhole velocity contrasts can be attributed to the transition from mafic to other lithologies, which dominates the uppermost borehole sections. Where core and downhole velocities show discrepancies, this can be ascribed to microcracks induced by the coring process (strain relief of the core), and this occurs more frequently in the gneissic lithologies. The applied methods and presented results are a good tool for future case studies and an extension to the available database. 


\section{Appendix A}

Table A1. List of investigated core samples, their exact core position, and associated International Geo Sampling Number (IGSN). The section tops refer to the meter-corrected depth from the operation data sets (Lorenz et al., 2019). FK - samples newly measured for this study; QW - samples originally measured by Wenning et al. (2016).

\begin{tabular}{lcccrrrll}
\hline Core & Section & Box & Slot & $\begin{array}{r}\text { Section } \\
\text { top } \\
(\mathrm{m})\end{array}$ & $\begin{array}{r}\text { Sample } \\
\text { top } \\
(\mathrm{cm})\end{array}$ & $\begin{array}{r}\text { Sample } \\
\text { bottom } \\
(\mathrm{cm})\end{array}$ & Examiner & IGSN \\
\hline 106 & 1 & 102 & 1 & 402.80 & 20 & 40 & FK & BGRB5054RXG9401 \\
143 & 1 & 135 & 1 & 501.76 & 20 & 40 & FK & BGRB5054RXI9401 \\
149 & 4 & 141 & 4 & 522.22 & 9 & 29 & FK & ICDP5054EXK6601 \\
193 & 2 & 184 & 2 & 649.51 & 0 & 15 & QW & ICDP5054EXL6601 \\
243 & 2 & 233 & 2 & 790.49 & 65 & 80 & QW & ICDP5054EXN6601 \\
361 & 2 & 343 & 3 & 1120.76 & 55 & 82.6 & FK & BGRB5054RXP9401 \\
487 & 1 & 467 & 1 & 1490.97 & 62 & 87 & QW & ICDP5054EXS6601 \\
556 & 2 & 528 & 3 & 1689.84 & 0 & 20 & QW & ICDP5054EXU6601 \\
569 & 2 & 542 & 3 & 1743.89 & 27 & 42 & FK & ICDP5054EXV6601 \\
593 & 4 & 575 & 4 & 1880.83 & 60 & 75 & FK & ICDP5054EX47601 \\
631 & 1 & 627 & 5 & 2096.96 & 60 & 78 & QW & ICDP5054EXY6601 \\
641 & 5 & 642 & 4 & 2160.49 & 0 & 20 & FK & BGRB5054RXY9401 \\
651 & 5 & 656 & 1 & 2220.29 & 10 & 30 & FK & BGRB5054RX0A401 \\
661 & 3 & 669 & 4 & 2278.43 & 77 & 95.8 & FK & BGRB5054RX1A401 \\
664 & 2 & 673 & 4 & 2295.51 & 70 & 85 & FK & ICDP5054EX6A601 \\
691 & 1 & 711 & 2 & 2456.64 & 54 & 69 & QW & ICDP5054EX27601 \\
\hline
\end{tabular}


Data availability. The underlying data to this research are available through the GFZ Data Services domain repository operated by the GFZ Library and Information Services of the Helmholtz Centre Potsdam - GFZ German Research Centre for Geosciences (https://doi.org/10.5880/icdp.5054.002, Lorenz et al., 2019).

Author contributions. FK and SP carried out the core measurements. FK and AZ conducted the laboratory measurements and analysis. FK prepared the paper with contributions from all coauthors. SP and CB are responsible for conceptualization and funding acquisition. All authors worked on the paper.

Competing interests. The authors declare that they have no conflict of interest.

Acknowledgements. Research funded by the Deutsche Forschungsgemeinschaft (DFG, German Research Foundation) - project no. 339380967 (SPP-1006). The COSC-1 borehole was drilled with the Swedish national research infrastructure for scientific drilling, Riksriggen, and funded by the Swedish Scientific Drilling Program (SSDP) through the Swedish Research Council (VR-2013-94) and the International Continental Scientific Drilling Program (ICDP). We thank Bjarne Almqvist, Henning Lorenz, Iwona Klonowska, Jaroslaw Majka, Christopher Juhlin, and Ulrich Harms for constructive and fruitful discussions during paper preparation. We are grateful to Claudio Madonna and Quinn Wenning for providing their support and advice during the preparation and measurements of the samples at the Rock Deformation Laboratory of the ETH Zurich. We would like to thank Ulli Raschke for his assistance and efforts during core logging with the multi-sensor core logger at the BGR core repository in Berlin-Spandau and Friederike Klos for providing logistical support for the sample material. Moreover, we thank Catalina Gebhardt for her advice on the processing of the MSCL data. We thank Anett Blischke and one anonymous reviewer for their valuable comments and suggestions, which have improved the paper considerably.

Financial support. This research is entirely funded by the Deutsche Forschungsgemeinschaft (SPP-1006, project no. 339380967) and was conducted as part of Felix Kästner's PhD research project.

The article processing charges for this open-access publication were covered by a Research Centre of the Helmholtz Association.

Review statement. This paper was edited by Michal Malinowski and reviewed by Anett Blischke and one anonymous referee.

\section{References}

Arnbom, J.-O.: Metamorphism of the Seve Nappes at Åreskutan, Swedish Caledonides, Geol. Foren. Stock. For., 102, 359-371, https://doi.org/10.1080/11035898009454493, 1980.

Babuska, V. and Cara, M.: Seismic anisotropy in the Earth, Kluwer Academic Publishers, Springer, Netherlands, https://doi.org/10.1007/978-94-011-3600-6, 1991.

Barberini, V., Burlini, L., and Zappone, A.: Elastic properties, fabric and seismic anisotropy of amphibolites and their contribution to the lower crust reflectivity, Tectonophysics, 445, 227-244, https://doi.org/10.1016/J.TECTO.2007.08.017, 2007.

Barblan, F.: Paramètres physiques expérimentaux de roches de la croûte continentale intermédiaire à profonde, Université de Genève, Geneva, Switzerland, 1990.

Bartetzko, A., Delius, H., and Pechnig, R.: Effect of compositional and structural variations on log responses of igneous and metamorphic rocks. I: mafic rocks, Geol. Soc. Spec. Publ., 240, 255278, https://doi.org/10.1144/GSL.SP.2005.240.01.19, 2005.

Bezacier, L., Reynard, B., Bass, J. D., Wang, J., and Mainprice, D.: Elasticity of glaucophane, seismic velocities and anisotropy of the subducted oceanic crust, Tectonophysics, 494, 201-210, https://doi.org/10.1016/j.tecto.2010.09.011, 2010.

Birch, F.: The velocity of compressional waves in rocks to 10 kilobars: 1., J. Geophys. Res., 65, 1083-1102, https://doi.org/10.1029/JZ065i004p01083, 1960.

Birch, F.: The velocity of compressional waves in rocks to 10 kilobars: 2., J. Geophys. Res., 66, 2199-2224, https://doi.org/10.1029/JZ066i007p02199, 1961.

Bloomer, S. F. and Mayer, L. A.: Core-log-seismic integration as a framework for determining the basin-wide significance of regional reflectors in the eastern equatorial Pacific, Geophys. Res. Lett., 24, 321-324, https://doi.org/10.1029/96GL02076, 1997.

Breitzke, M. and Spieß, V.: An automated full waveform logging system for high-resolution P-wave profiles in marine sediments, Mar. Geophys. Res., 15, 297-321, 1993.

Corfu, F., Gasser, D., and Chew, D. M.: New perspectives on the Caledonides of Scandinavia and related areas: introduction, Geol. Soc. Spec. Publ., 390, 1-8, https://doi.org/10.1144/SP390.28, 2014.

Crampin, S.: Suggestions for a consistent terminology for seismic anisotropy, Geophys. Prospect., 37, 753-770, https://doi.org/10.1111/j.1365-2478.1989.tb02232.x, 1989.

Dresen, G. and Guéguen, Y.: Damage and Rock Physical Properties, in Mechanics of Fluid-Saturated Rocks, chap. 4, International Geophysics, 89, 169-217, 2004.

Ebbing, J., England, R. W., Korja, T., Lauritsen, T., Olesen, O., Stratford, W., and Weidle, C.: Structure of the Scandes lithosphere from surface to depth, Tectonophysics, 536-537, 1-24, https://doi.org/10.1016/J.TECTO.2012.02.016, 2012.

Elbra, T., Karlqvist, R., Lassila, I., Haeggström, E., and Pesonen, L. J.: Laboratory measurements of the seismic velocities and other petrophysical properties of the Outokumpu deep drill core samples, eastern Finland, Geophys. J. Int., 184, 405-415, https://doi.org/10.1111/j.1365-246X.2010.04845.x, 2011.

Falus, G., Tommasi, A., and Soustelle, V.: The effect of dynamic recrystallization on olivine crystal preferred orientations in mantle xenoliths deformed under varied stress conditions, J. Struct. Geol., 33, 1528-1540, https://doi.org/10.1016/J.JSG.2011.09.010, 2011. 
Fountain, D. M.: The Ivrea-Verbano and Strona-Ceneri Zones, Northern Italy: A cross-section of the continental crust-New evidence from seismic velocities of rock samples, Tectonophysics, 33, 145-165, 1976.

Galvin, R. J. and Gurevich, B.: Frequency-dependent anisotropy of porous rocks with aligned fractures, Geophys. Prospect., 63, 141-150, https://doi.org/10.1111/1365-2478.12177, 2015.

Gee, D. G. and Sturt, B. A. (Eds.): The Caledonide orogen: Scandinavia and related areas, Wiley, Chichester, New York, 1985.

Gee, D. G., Fossen, H., Henriksen, N., and Higgins, A. K.: From the early Paleozoic platforms of Baltica and Laurentia to the Caledonide Orogen of Scandinavia and Greenland, Episodes, 31, 44$51,2008$.

Gee, D. G., Juhlin, C., Pascal, C., and Robinson, P.: Collisional Orogeny in the Scandinavian Caledonides (COSC), GFF, 132, 29-44, https://doi.org/10.1080/11035891003759188, 2010.

Gee, D. G., Janák, M., Majka, J., Robinson, P., and van Roermund, H.: Subduction along and within the baltoscandian margin during closing of the lapetus ocean and baltica-laurentia collision, Lithosphere, 5, 169-178, https://doi.org/10.1130/L220.1, 2013.

Golovataya, O. S., Gorbatsevich, F. F., Kern, H., and Popp, T.: Properties of some rocks from the section of the Kola ultradeep borehole as a function of the $P-T$ parameters, Izv.-Phys. Solid Eart., 42, 865-876, 2006.

Grab, M., Zürcher, B., Maurer, H., and Greenhalgh, S.: Seismic velocity structure of a fossilized Icelandic geothermal system: A combined laboratory and field study, Geothermics, 57, 84-94, https://doi.org/10.1016/j.geothermics.2015.06.004, 2015.

Hedin, P., Juhlin, C., and Gee, D. G.: Seismic imaging of the Scandinavian Caledonides to define ICDP drilling sites, Tectonophysics, 554-557, 30-41, https://doi.org/10.1016/J.TECTO.2012.05.026, 2012.

Hedin, P., Malehmir, A., Gee, D. G., Juhlin, C., and Dyrelius, D.: 3D interpretation by integrating seismic and potential field data in the vicinity of the proposed COSC-1 drill site, central Swedish Caledonides, Geolog. Soc. Spec. Publ., 390, 301-319, https://doi.org/10.1144/SP390.15, 2014.

Hedin, P., Almqvist, B., Berthet, T., Juhlin, C., Buske, S., Simon, H., Giese, R., Krauß, F., Rosberg, J. E., and Alm, P. G.: 3D reflection seismic imaging at the $2.5 \mathrm{~km}$ deep COSC- 1 scientific borehole, central Scandinavian Caledonides, Tectonophysics, 689, 40-55, https://doi.org/10.1016/j.tecto.2015.12.013, 2016.

Ji, S., Wang, Q., Marcotte, D., Salisbury, M. H., and Xu, Z.: P wave velocities, anisotropy and hysteresis in ultrahigh-pressure metamorphic rocks as a function of confining pressure, J. Geophys. Res., 112, B09204, https://doi.org/10.1029/2006JB004867, 2007.

Juhlin, C.: Interpretation of the reflections in the Siljan Ring area based on results from the Gravberg-1 borehole, Tectonophysics, 173, 345-360, 1990

Juhlin, C., Hedin, P., Gee, D. G., Lorenz, H., Kalscheuer, T., and Yan, P.: Seismic imaging in the eastern Scandinavian Caledonides: siting the $2.5 \mathrm{~km}$ deep COSC-2 borehole, central Sweden, Solid Earth, 7, 769-787, https://doi.org/10.5194/se-7-7692016, 2016.

Keppler, R., Behrmann, J. H., and Stipp, M.: Textures of eclogites and blueschists from Syros island, Greece: Inferences for elastic anisotropy of subducted oceanic crust, J. Geophys. Res.-Sol. Ea., 122, 5306-5324, https://doi.org/10.1002/2017JB014181, 2017.
Kern, H.: The effect of high temperature and high confining pressure on compressional wave velocities in quartz-bearing and quartz-free igneous and metamorphic rocks, Tectonophysics, 44, 185-203, https://doi.org/10.1016/0040-1951(78)90070-7, 1978.

Kern, H.: Elastic-wave velocity in crustal and mantle rocks at high pressure and temperature: the role of the high-low quartz transition and of dehydration reactions, Phys. Earth Planet. In., 29, 12-23, https://doi.org/10.1016/0031-9201(82)90133-9, 1982.

Kern, H.: Laboratory seismic measurements: an aid in the interpretation of seismic field data, Terra Nova, 2, 617-628, https://doi.org/10.1111/j.1365-3121.1990.tb00127.x, 1990.

Kern, H. and Wenk, H.-R.: Fabric-related velocity anisotropy and shear wave splitting in rocks from the Santa Rosa Mylonite Zone, California, J. Geophys. Res., 95, 11213-11223, https://doi.org/10.1029/JB095IB07P11213, 1990.

Kern H., Schmidt R., and Popp T.: The velocity and density structure of the $4000 \mathrm{~m}$ crustal segment at the KTB drilling site and their relationship to lithological and microstructural characteristics of the rocks: an experimental approach, Scientific Drilling, 2, 130-145, 1991.

Kingdon, A., Rogers, S. F., Evans, C. J., and Brereton, N. R.: The comparison of core and geophysical log measurements obtained in the Nirex investigation of the Sellafield region, Geol. Soc. Spec. Publ., 136, 97-113, 1998.

Klonowska, I., Janák, M., Majka, J., Petrík, I., Froitzheim, N., Gee, D. G., and Sasinková, V.: Microdiamond on Åreskutan confirms regional UHP metamorphism in the Seve Nappe Complex of the Scandinavian Caledonides, J. Metamorph. Geol., 35, 541-564, https://doi.org/10.1111/jmg.12244, 2017.

Krauß, F.: Combination of Borehole Seismic and Downhole Logging to Investigate the Vicinity of the COSC-1 Borehole in Western Scandinavia, TU Bergakademie Freiberg, Freiberg, Germany, 2017.

Krauß, F., Simon, H., Giese, R., Buske, S., Hedin, P., and Juhlin, C.: Zero-Offset VSP in the COSC-1 borehole, EGU General Assembly, Vienna, Austria, 12-17 April 2015, EGU2015-3255, 2015.

Kukkonen, I. T. (Ed.): Outokumpu deep drilling project 2003-2010, Geological Survey of Finland, Espoo, 2011.

Labrousse, L., Hetényi, G., Raimbourg, H., Jolivet, L., and Andersen, T. B.: Initiation of crustal-scale thrusts triggered by metamorphic reactions at depth: Insights from a comparison between the Himalayas and Scandinavian Caledonides, Tectonics, 29, TC5002, https://doi.org/10.1029/2009TC002602, 2010.

Ladenberger, A., Be'eri-Shlevin, Y., Claesson, S., Gee, D. G., Majka, J., and Romanova, I. V.: Tectonometamorphic evolution of the Åreskutan Nappe - Caledonian history revealed by SIMS U$\mathrm{Pb}$ zircon geochronology, Geolog. Soc. Spec. Publ., 390, 337 368, https://doi.org/10.1144/SP390.10, 2014.

Lorenz, H., Rosberg, J.-E., Juhlin, C., Bjelm, L., Almqvist, B. S. G., Berthet, T., Conze, R., Gee, D. G., Klonowska, I., Pascal, C., Pedersen, K., Roberts, N. M. W., and Tsang, C.-F.: COSC1 - drilling of a subduction-related allochthon in the Palaeozoic Caledonide orogen of Scandinavia, Sci. Dril., 19, 1-11, https://doi.org/10.5194/sd-19-1-2015, 2015a.

Lorenz, H., Rosberg, J.-E., Juhlin, C., Bjelm, L., Almqvist, B., Berthet, T., Conze, R., Gee, D. G., Klonowska, I., Pascal, C., Pedersen, K., Roberts, N., and Tsang, C.: COSC-1 operational report - Operational data sets, GFZ Data Services, https://doi.org/10.1594/GFZ.SDDB.ICDP.5054.2015, 2015b. 
Lorenz, H., Rosberg, J.-E., Juhlin, C., Bjelm, L., Almqvist, B., Berthet, T., Conze, R., Gee, D. G., Klonowska, I., Pascal, C., Pedersen, K., Roberts, N., and Tsang, C.: COSC-1 operational report - Operational data sets, version 1.2, GFZ Data Services, https://doi.org/10.5880/ICDP.5054.002, 2019.

Lowell, S., Shields, J. E., Thomas, M. A., and Thommes, M.: Characterization of Porous Solids and Powders: Surface Area, Pore Size and Density, 1st edn., Springer, Dordrecht, Netherlands, 2004.

Majka, J., Rosén, Å., Janák, M., Froitzheim, N., Klonowska, I., Manecki, M., Sasinková, V., and Yoshida, K.: Microdiamond discovered in the Seve Nappe (Scandinavian Caledonides) and its exhumation by the "vacuum-cleaner" mechanism, Geology, 42, 1107-1110, https://doi.org/10.1130/G36108.1, 2014.

Miller, K., Browning, J. V., Mountain, G. S., Bassetti, M. A., Monteverde, D., Katz, M. E., Inwood, J., Lofi, J., and Proust, J.-N.: Sequence boundaries are impedance contrasts: Core-seismic-log integration of Oligocene-Miocene sequences, New Jersey shallow shelf, Geosphere, 9, 1257, https://doi.org/10.1130/GES00858.1, 2013.

Motra, H. B. and Stutz, H. H.: Geomechanical Rock Properties Using Pressure and Temperature Dependence of Elastic P- and SWave Velocities, Geotechnical and Geological Engineering, 36, 3751-3766, https://doi.org/10.1007/s10706-018-0569-9, 2018.

Nur, A. and Simmons, G.: Stress-induced velocity anisotropy in rock: An experimental study, J. Geophys. Res., 74, 6667-6674, https://doi.org/10.1029/JB074i027p06667, 1969.

Pechnig, R., Haverkamp, S., Wohlenberg, J., Zimmermann, G., and Burkhardt, H.: Integrated log interpretation in the German Continental Deep Drilling Program: Lithology, porosity, and fracture zones, J. Geophys. Res., 102, 18363-18390, https://doi.org/10.1029/96JB03802, 1997.

Pechnig, R., Delius, H., and Bartetzko, A.: Effect of compositional variations on $\log$ responses of igneous and metamorphic rocks. II: Acid and intermediate rocks, Geolog. Soc. Spec. Publ., 240, 279-300, https://doi.org/10.1144/GSL.SP.2005.240.01.20, 2005.

Riedel, M., Bahk, J. J., Kim, H. S., Yoo, D. G., Kim, W. S., and Ryu, B. J.: Seismic facies analyses as aid in regional gas hydrate assessments. Part-I: Classification analyses, Mar. Petrol. Geol., 47, 248-268, 2013.

Roberts, D. and Gee, D. G.: An introduction to the structure of the Scandinavian Caledonides, in: The Caledonide Orogen: Scandinavia and Related Areas, edited by: Gee, D. G. and Sturt, B. A., Wiley, Chichester, New York, 55-68, 1985.

Schön, J.: Physical properties of rocks: fundamentals and principles of petrophysics, Pergamon, Oxford, 1996.

Serra, O.: Fundamentals of Well-Log Interpretation, 1. The Acquisition of Logging Data, Elsevier, Amsterdam, 1984.

Shaocheng, J. and Mainprice, D.: Natural deformation fabrics of plagioclase: implications for slip systems and seismic anisotropy, Tectonophysics, 147, 145-163, 1988.

Siegesmund, S., Kern, H., and Vollbrecht, A.: The effect of oriented microcracks on seismic velocities in an ultramylonite, Tectonophysics, 186, 241-251, 1991.

Simon, H., Krauß, F., Hedin, P., Buske, S., Giese, R., and Juhlin, C.: A combined surface and borehole seismic survey at the COSC-1 borehole, EGU General Assembly, Vienna, Austria, 12-17 April 2015, EGU2015-4554, 2015.
Strömberg, A., Karis, L., Zachrisson, E., Sjöstrand, T., and Skogland, R.: Bedrock Geological Map of Jämtland County (Caledonides), scale 1:200000, Sveriges Geologiska Undersökning, Ca 53, Uppsala, 1994.

Sun, S., Ji, S., Wang, Q., Xu, Z., Salisbury, M., and Long, C.: Seismic velocities and anisotropy of core samples from the Chinese Continental Scientific Drilling borehole in the Sulu UHP terrane, eastern China, J. Geophys. Res., 117, B01206, https://doi.org/10.1029/2011JB008672, 2012.

Taylor, J.: An introduction to error analysis : the study of uncertainties in physical measurements, University Science Books, New York, 1997.

Thomsen, L.: Elastic anisotropy due to aligned cracks in porous rock, Geophys. Prospect., 43, 805-829, 1995.

Thu, M. K., Tamaki, K., Kuramoto, S.-I., Tada, R., and Saito, S.: High-resolution seismic stratigraphy of the Yamato Basin, Japan Sea and its geological application, Isl. Arc, 11, 61-78, https://doi.org/10.1046/j.1440-1738.2002.00352.x, 2002.

Urmos, J., Wilkens, R. H., Bassinot, F., Lyle, M., Marsters, J. C., Mayer, L. A., and Mosher, D. C.: Laboratory and Well-Log Velocity and Density Measurements from the Ontong Java Plateau: New in-situ corrections to laboratory data for pelagic carbonates, in: Proceedings of the Ocean Drilling Program: Scientific Results, 130, 607-622, 1993.

Weber, M. E., Niessen, F., Kuhn, G., and Wiedicke, M.: Calibration and application of marine sedimentary physical properties using a multi-sensor core logger, Mar. Geol., 136, 151-172, https://doi.org/10.1016/S0025-3227(96)00071-0, 1997.

Wenning, Q. C., Almqvist, B., Hedin, P., and Zappone, A.: Seismic anisotropy in mid to lower orogenic crust: Insights from laboratory measurements of $\mathrm{Vp}$ and $\mathrm{Vs}$ in drill core from central Scandinavian Caledonides, Tectonophysics, 692, 14-28, https://doi.org/10.1016/j.tecto.2016.07.002, 2016.

Wenning, Q. C., Berthet, T., Ask, M., Zappone, A., Rosberg, J.E., and Almqvist, B. S. G.: Image log analysis of in situ stress orientation, breakout growth, and natural geologic structures to $2.5 \mathrm{~km}$ depth in central Scandinavian Caledonides: Results from the COSC-1 borehole, J. Geophys. Res.-Sol. Ea., 122, 39994019, https://doi.org/10.1002/2016JB013776, 2017.

Wepfer, W. W. and Christensen, N. I.: A seismic velocity-confining pressure relation, with applications, Int. J. Rock Mech. Min., 28, 451-456, https://doi.org/10.1016/0148-9062(91)90083-X, 1991.

Wolter, K. E. and Berckhemer, H.: Time dependent strain recovery of cores from the KTB - Deep drill hole, Rock Mech. Rock Eng., 22, 273-287, https://doi.org/10.1007/BF01262283, 1989.

Worthington, P. F.: Effective integration of core and log data, Mar. Petrol. Geol., 11, 457-466, 1994.

Zang, A. and Stephansson, O.: Stress Field of the Earth's Crust, Springer, Netherlands, 2010.

Zang, A., Wolter, K., and Berckhemer, H.: Strain recovery, microcracks and elastic anisotropy of drill cores from KTB deep well, Scientific drilling: geophysics, geochemistry, and technology, 1, 115-126, 1989.

Zappone, A., Fernàndez, M., Garcı̀̀-Dueñas, V., and Burlini, L.: Laboratory measurements of seismic P-wave velocities on rocks from the Betic chain (southern Iberian Peninsula), Tectonophysics, 317, 259-272, https://doi.org/10.1016/S00401951(99)00319-4, 2000. 